NEIRA, Ana María. "La efectividad de los criminal compliance programs como objeto de prueba en el proceso penal".

Polít. crim. Vol. 11, No 22 (Diciembre 2016), Art. 5, pp. 467-520.

[http://www.politicacriminal.cl/Vol_11/n_22/Vol11N22A5.pdf]

\title{
La efectividad de los criminal compliance programs como objeto de prueba en el proceso penal
}

\section{Effectiveness of criminal compliance programs as the object of proof in criminal proceedings}

\author{
Ana María Neira Pena* \\ Doctora en Derecho por la Universidade da Coruña (España) \\ Profesora Ayudante del área de Derecho Procesal de la Universidade da Coruña \\ ana.neira@udc.es
}

\section{Resumen}

En algunos países pertenecientes a la tradición del civil law, tales como España, Italia y Chile, sólo recientemente se ha regulado la responsabilidad penal de las personas jurídicas. Como consecuencia, surgen ciertas obligaciones de autorregulación para las empresas, que se ven fuertemente incentivadas a implementar programas de prevención y detección de delitos para evitar incurrir en responsabilidad por los delitos cometidos por sus agentes. A la luz de este nuevo escenario legal, en una primera parte de este artículo, se analizarán los elementos que debe contener un programa de cumplimiento penal para ser considerado eficaz, de tal forma que su implementación efectiva en la organización permita a la empresa quedar exenta de responsabilidad. En segundo lugar, el análisis se centrará en la cuestión clave de cómo probar la eficacia de tales programas en el proceso penal, esto es, en determinar qué medios de prueba son idóneos a tal fin, quién tiene la carga de probar la vigencia y la eficacia de tales programas en la organización y quién debe sufrir las consecuencias de la falta o la insuficiencia de la prueba.

Palabras clave: Programas de cumplimiento eficaces, responsabilidad penal de empresa, proceso penal, medios de prueba, carga de la prueba.

\begin{abstract}
In some countries belonging to the civil law tradition, such as Spain, Italy and Chile, corporate criminal liability has been regulated recently. As a consequence, certain selfregulation obligations emerge. Corporations are strongly encouraged to implement programs of prevention and detection of crimes to avoid being criminally responsible for

\footnotetext{
* Trabajo realizado en el marco del proyecto "El sistema penal español en el periodo post-crisis" $\left(\mathrm{n}^{\circ}\right.$ referencia: DER2014-52674-R) subvencionado por la Secretaría de Estado de Investigación, Desarrollo e Innovación del Ministerio de Economía y Competitividad. Convocatoria 2015 del Programa estatal de Investigación, Desarrollo e Innovación orientada a los Retos de la Sociedad. Trabajo realizado en el marco de la ayuda para grupos de referencia competitiva ( ${ }^{\circ}$ referencia GRC2015/021) otorgada por la Consellería de Cultura, Educación y Ordenación Universitaria de la Xunta de Galicia al grupo ECRIM de la Universidade da Coruña (DOG de 30/IX/2015).
} 
NEIRA, Ana María. "La efectividad de los criminal compliance programs como objeto de prueba en el proceso penal".

crimes committed by their agents. In the light of this new legal scenario, this article in its first part analyzes the elements that criminal compliance programs should contain to be considered effective, in such a way that its effective implementation within the organization allows the corporation be exempted from liability. Secondly, the analysis will focus on the key issue of how to prove the effectiveness of such programs at a trial, that is, what means of evidence are suitable for this purpose, who has the burden of proving the validity and effectiveness of such programs and who must suffer the consequences of the lack or insufficiency of evidence.

Key words: Effective compliance programs, corporate criminal liability, criminal proceedings, means of evidence, burden of proof.

\section{Introducción.}

La introducción de sistemas legales de responsabilidad penal de las personas jurídicas en algunos ordenamientos jurídicos en los que, tradicionalmente, ha estado vigente el principio societas deliquere non potest, obliga a plantearse, desde la perspectiva procesal, qué elementos habrán de ser probados para que una entidad pueda resultar condenada tras la celebración del pertinente juicio penal, así como qué elementos habrá de alegar y probar la entidad, como parte de su estrategia de defensa, para resultar absuelta o, en su caso, ver atenuada su responsabilidad, a pesar de haberse cometido un delito en su seno.

La mayor parte de los sistemas legales establecen modelos de autorresponsabilidad empresarial. Estos se caracterizan porque la responsabilidad de la organización, aunque presupone la comisión de un delito por una persona física, se fundamenta en el incumplimiento de ciertos deberes de dirección y supervisión por parte de la propia organización. Pues bien, en este tipo de sistemas legales, los criminal compliance programs desarrollan un papel fundamental en el cumplimiento, por parte de la organización, de sus deberes de prevención y detección de ilícitos penales.

Si una persona jurídica cuenta con un programa de prevención de delitos eficaz puede evitar ser acusada y juzgada, puede quedar exenta de responsabilidad tras el correspondiente juicio penal o, en el peor de los escenarios para la entidad, puede resultar condenada, si bien con una sustancial rebaja de su pena. En este contexto, lo que se entiende por un programa de cumplimiento penal eficaz y el modo en que tal eficacia puede ser probada en juicio son cuestiones de transcendental importancia.

Por lo tanto, partiendo de la relevancia de los programas de cumplimiento normativo como objeto de prueba, en aquellos procesos penales en que se enjuicie la responsabilidad criminal de una persona jurídica, habrá que determinar cuáles son los medios de prueba idóneos para acreditar procesalmente la eficacia de tales programas. La prueba documental resulta clave ya que sirve para introducir en el proceso los códigos, las políticas y los protocolos de actuación diseñados por la entidad para el desarrollo de su tarea de prevención delictiva, así como aquellas evidencias, en papel o electrónicas, que la aplicación práctica del programa vaya generando, asegurando, de este modo, la trazabilidad de la actividad de cumplimiento penal. Sin embargo, en tanto que tales programas deben 
encontrase efectivamente vigentes en las dinámicas y actividades de la organización y deben de ser supervisados, actualizados y, en su caso, certificados o auditados por entidades independientes, la prueba documental resulta insuficiente, debiendo completarse con testificales y periciales que acrediten la vigencia del programa, su carácter dinámico, su capacidad para condicionar el comportamiento de los miembros de la organización y, en definitiva, el compromiso de la entidad con la cultura de cumplimiento de la legalidad que debe regir sus actuaciones.

Otra cuestión clave y muy controvertida es la relativa a la carga de la prueba en relación con la idoneidad, la vigencia y la efectividad de tales modelos de prevención. A este respecto, es necesario analizar si es la acusación la encargada de probar que la entidad no ha implementado de forma eficaz el modelo, o si, por el contrario, es la persona jurídica la que debe acreditar que, a pesar de haberse cometido un delito en su seno, desde la organización se actuó diligentemente en la implementación de las medidas adecuadas para prevenir tal acaecimiento. La solución a este problema aparece vinculada, en parte, al entendimiento dogmático de los modelos de prevención, ya como elementos del tipo penal imputable a las personas jurídicas, ya como circunstancias eximentes de la culpabilidad empresarial.

\section{Qué es un modelo de prevención de delitos eficaz.}

\subsection{Concepto y denominación legal.}

Los compliance programs son sistemas organizativos que incluyen principios, reglas, procedimientos e instrumentos orientados a asegurar el cumplimiento de la legalidad en el desarrollo de las actividades de una organización, mientras que los criminal compliance programas, en los que se centra este trabajo, constituyen sistemas de organización empresarial, que también tienden a garantizar el cumplimiento normativo, si bien limitados a asegurar la observancia de la normativa jurídico-penal por parte de la empresa ${ }^{1}$. Por lo tanto, el criminal compliance tiene un ámbito mucho más limitado, circunscrito a prevenir el riesgo de comisión de delitos, de tal forma que su implementación es más sencilla, dado que su eficacia en la prevención de riesgos queda limitada a este sector de la legalidad, cual es el Derecho Penal ${ }^{2}$.

Estos programas constituyen una ordenación intraempresarial vinculante para los trabajadores y directivos de la entidad, por lo que, a pesar de su naturaleza privada, cabe

\footnotetext{
${ }^{1}$ Cfr. BOCK, Dennis, "Compliance y deberes de vigilancia en la empresa", en: KUHLEN, Lothar; MONTIEL, Juan Pablo; ORTIZ DE URBINA GIMENO, Íñigo (Eds.), Compliance y teoría del Derecho Penal, Madrid: Marcial Pons, 2013, pp. 107-124, p. 108.xc

2 Tal y como afirma NIETO MARTÍN, Adán, "Problemas fundamentales del cumplimiento normativo en el Derecho penal”, en: KUHLEN, Lothar; MONTIEL, Juan Pablo; ORTIZ DE URBINA GIMENO, Íñigo (Eds.) Compliance y teoría del Derecho Penal, Madrid: Marcial Pons, 2013, pp. 21-50, p. 28, "el cumplimiento normativo debe comenzar normalmente mucho antes del tipo penal”, de tal suerte que los estándares de prevención desarrollados por la normativa extrapenal, ya administrativa, ya proveniente de la autorregulación empresarial, deberían ser válidos, así mismo, para cumplir con los estándares de cumplimiento del Derecho Penal en tanto que ultima ratio.
} 
NEIRA, Ana María. "La efectividad de los criminal compliance programs como objeto de prueba en el proceso penal".

señalar que revisten un valor cuasi-normativo ${ }^{3}$. De hecho, se afirma que, el criminal compliance, en la medida en que persigue el respeto de la legalidad penal y la neutralización de los riesgos penales, asume cierto carácter de orden público ${ }^{4}$.

En lengua castellana, la expresión criminal compliance programs podría ser traducida como programas de cumplimiento normativo penal, si bien, la propuesta Código Procesal Penal española, que no llegó a tramitarse en la legislatura, los denominaba sistemas de control interno y en la terminología del Código Penal español vigente (en adelante, CP) son designados como modelos de organización y gestión. Por su parte, la legislación italiana contenida en el Decreto Legislativo de 8 de junio de 2001, no 231, D. Lgs. n. 231/2001 "Disciplina della responsabilità amministrativa delle persone giuridiche, delle società e delle associazioni anche prive di personalità giuridica" (en adelante, D. Lgs. 231), se refiere a ellos como modelli di organizzazione, mientras que la regulación chilena, contenida en la Ley $n^{\circ} 20.393$, de 2 de diciembre de 2019, que establece la responsabilidad penal de las personas jurídicas en los delitos de lavado de activos, financiamiento del terrorismo y delitos de cohecho (en adelante, Ley 20.393), habla de modelos de prevención de delitos. Por último, atendiendo a la normativa internacional podríamos referirnos a sistemas de gestión de compliance penal dado que la ISO 19600 regula, precisamente, el estándar en materia en "Sistemas de gestión de compliance".

Sea cual sea la denominación que se emplee, tales sistemas organizativos vienen integrados por un conjunto de medidas o mecanismos que adopta una entidad para prevenir y descubrir los delitos que pudieran cometerse en su seno. De hecho, de esta forma descriptiva se refiere a ellos el CP español en el art. 31 quáter d), al contemplarlos como circunstancia atenuante, cuando se adoptan de forma posterior a la comisión del delito.

\subsection{La regulación legal y el contenido mínimo de los modelos de prevención de delitos.}

La regulación española sobre la responsabilidad penal de las personas jurídicas, al igual que las leyes especiales que regulan la cuestión en Italia y Chile, o las Federal Sentencing Guidelines americanas (en adelante, U.S.S.G. ${ }^{5}$ ), recogen un elenco de elementos que han de contener los programas de prevención de delitos. Se trata, en cualquier caso, de requisitos orientativos, que indican el contenido mínimo que, en principio, debiera tener el modelo de gestión empresarial para ser considerado efectivo en la función de prevención y detección delictiva.

\footnotetext{
${ }^{3}$ GOÑI SEIN, José Luis, "Programas de cumplimiento empresarial (compliance programs): aspectos laborales", en: MIR PUIG, Santiago; CORCOY BIDASOLO, Mirentxu; GÓMEZ MARTÍN, Víctor (Dirs.); HORTAL IBARRA, Juan Carlos; VALIENTE IBÁÑEZ, Vicente (Coords.), Responsabilidad de la empresa y compliance. Programas de prevención, detección y reacción penal, Montevideo-Buenos Aires: B de F, 2014, pp. 367-419, p. 368.

${ }_{5}^{4}$ GOÑ SEIN, "Programas de cumplimiento empresarial", cit. nota $n^{\mathrm{o}} 3$, p. 383.

5 United States Sentencing Commission, Guidelines Manual, disponible en: http://www.ussc.gov/guidelines/2015-guidelines-manual [visitado el 12.07.2016]
} 
El art. 31 bis 5 CP se ha inspirado, claramente, en la regulación italiana, por lo que presenta un contenido prácticamente idéntico al art. 6. 2 D. Lgs. $231^{6}$. Igualmente, se observa que la Ley 20.393 está muy influenciada por la regulación italiana la cual, a su vez, bebe de la regulación estadounidense contenida en el capítulo 8 U.S.S.G. ${ }^{7}$.

Según las regulaciones española, italiana y chilena, la adopción de un programa de prevención de delitos eficaz, exige, en primer lugar, que se identifiquen las actividades en cuyo ámbito podrían cometerse los delitos a prevenir (arts. 6.2.a) D. Lgs. 231, 31 bis 5. $1^{\circ}$ CP y $4^{\circ} .3$ ) a) Ley 20.393). De esta prescripción legal se deriva la necesidad de desarrollar una labor de análisis y evaluación de riesgos, a través de la cual se confeccione un mapa de riesgos delictivos, en el que se cataloguen los delitos que podrían cometerse en el desarrollo de la actividad de la organización y se valore su probabilidad de comisión en los distintos subprocesos de la entidad, así como el impacto y las consecuencias de que, eventualmente, tal infracción penal llegue a cometerse ${ }^{8}$.

\footnotetext{
${ }^{6}$ La influencia de la regulación italiana resulta evidente, en tanto que muchas de las disposiciones del CP español constituyen traducciones prácticamente literales de la normativa italiana. Así pues, el art. 6.2 D. Lgs. 231 dispone que los modelos de prevención deben responder a las siguientes exigencias: a) individuare le attivita' nel cui ambito possono essere commessi reati; b) prevedere specifici protocolli diretti a programmare la formazione e l'attuazione delle decisioni dell'ente in relazione ai reati da prevenire; c) individuare modalita' di gestione delle risorse finanziarie idonee ad impedire la commissione dei reati; d) prevedere obblighi di informazione nei confronti dell'organismo deputato a vigilare sul funzionamento e l'osservanza dei modelli; e) introdurre un sistema disciplinare idoneo a sanzionare il mancato rispetto delle misure indicate nel modelo. Igualmente, el art. 7.4.a) D. Lgs. 231 señala que: "L'efficace attuazione del modello richiede una verifica periodica e l'eventuale modifica dello stesso quando sono scoperte significative violazioni delle prescrizioni ovvero quando intervengono mutamenti nell'organizzazione o nell'attivita'". Análogamente, el art. 31 bis $5 \mathrm{CP}$, viene a señalar que los modelos de organización y gestión, para tener eficacia eximente, "1.- Identificarán las actividades en cuyo ámbito puedan ser cometidos los delitos que deben ser prevenidos. 2.- Establecerán los protocolos o procedimientos que concreten el proceso de formación de la voluntad de la persona jurídica, de adopción de decisiones y de ejecución de las mismas con relación a aquéllos. 3.- Dispondrán de modelos de gestión de los recursos financieros adecuados para impedir la comisión de los delitos que deben ser prevenidos. 4.- Impondrán la obligación de informar de posibles riesgos e incumplimientos al organismo encargado de vigilar el funcionamiento y observancia del modelo de prevención. 5.- Establecerán un sistema disciplinario que sancione adecuadamente el incumplimiento de las medidas que establezca el modelo. 6.- Realizarán una verificación periódica del modelo y de su eventual modificación cuando se pongan de manifiesto infracciones relevantes de sus disposiciones, o cuando se produzcan cambios en la organización, en la estructura de control o en la actividad desarrollada que los hagan necesarios".

7 Esta normativa está disponible en: http://www.ussc.gov/sites/default/files/pdf/guidelinesmanual/2014/CHAPTER 8.pdf [visitado el 12.07.2016]. Un análisis de las U.S.S.G., que sólo puntualmente serán referidas en este trabajo, puede verse, al hilo del análisis del contenido de los programas de cumplimiento de acuerdo con la práctica internacional, en ARTAZA VARELA, Osvaldo, "Programas de cumplimiento. Breve descripción de las reglas técnicas de gestión del riesgo empresarial y su utilidad jurídico-penal", en: MIR PUIG, Santiago; CORCOY BIDASOLO, Mirentxu; GÓMEZ MARTÍN, Víctor (Dirs.); HORTAL IBARRA, Juan Carlos; VALIENTE IBÁÑEZ, Vicente (Coords.), Responsabilidad de la empresa y compliance. Programas de prevención, detección y reacción penal, Montevideo-Buenos Aires: B de F, 2014, pp. 231-271, pp. 242-265.

${ }^{8}$ A tal fin, ARTAZA VARELA, "Programas de cumplimiento", cit. nota $\mathrm{n}^{\circ}$ 7, pp. 250-252, recomienda emplear la metodología de evaluación de riesgos empresarial propuesta por el Committe of Sponsoring Organizations of the Treadway Commission (COSO), que distingue entre la etapa de planificación y la de gestión del riesgo, que a su vez incluye la identificación, la evaluación, la priorización y planificación de respuesta y el monitoreo del riesgo.
} 
NEIRA, Ana María. "La efectividad de los criminal compliance programs como objeto de prueba en el proceso penal".

Junto con los específicos riesgos inherentes al objeto social que desarrolle la entidad, su actividad financiera se considera ex lege como un área de riesgo. Por eso, en la gestión de los recursos financieros, la normativa, expresamente, demanda la existencia de reglas orientadas a prevenir delitos (art. 6.2.c) D. Lgs. 231, art. 31 bis $5.3^{\circ} \mathrm{CP}$ y art. $4.3^{\circ}$. c) Ley 20.393). Normalmente, estas reglas o protocolos consistirán en ciertas obligaciones de registro y archivo de operaciones financieras o de tesorería, así como en la distribución clara de responsabilidades en relación con las áreas o departamentos de la empresa con atribuciones en la administración de los recursos financieros. Además, será necesario auditar o establecer controles periódicos sobre la actividad financiera para detectar posibles irregularidades o incumplimientos de los protocolos adoptados.

En segundo lugar, el modelo de prevención de delitos establecerá protocolos de actuación orientados a minimizar la probabilidad de que se materialicen los riesgos delictivos previamente identificados. Esto implica formalizar los procedimientos de la entidad de formación de su voluntad, de toma de decisiones y de ejecución de las mismas, con el fin de establecer controles, tanto preventivos como reactivos, en aquellos subprocesos identificados como arriesgados en términos penales, buscando la manera de reducir tales riesgos (6.2.b) D. Lgs. 231 y art. 31 bis 5. $2^{\circ} \mathrm{CP}$ ). En la misma línea, la regulación chilena requiere que los programas de prevención de delitos establezcan protocolos, reglas y procedimientos específicos que permitan a las personas que intervengan en las actividades o procesos de la entidad identificados como riesgosos en términos de comisión de delitos, programar y ejecutar sus tareas o labores de una manera que prevenga la comisión de delitos (art. $4^{\circ}$ 3) b) Ley 20.393).

Esta protocolización de las actividades de la entidad, consideradas clave en términos de comisión de delitos, requiere, actuar en varios ámbitos. En primer lugar, exige informar al personal sobre los deberes y prohibiciones que han de respetar en el desarrollo de su actividad, así como formarlo y capacitarlo en lo que significa e implica, en relación con sus concretas funciones en la empresa, la política de cumplimiento de la legalidad. Así mismo, precisa de la existencia de un sistema de incentivos adecuado que estimule a los trabajadores a actuar en conformidad con la ley ${ }^{9}$. En segundo lugar, demanda el establecimiento de ciertas obligaciones de documentación y archivo de determinadas actividades $\mathrm{u}$ operaciones, que obliguen al personal a seguir los cauces de actuación establecidos por la organización y que permitan a la entidad detectar posibles desviaciones. $\mathrm{Y}$, en tercer lugar, necesita de un sistema adecuado de delegación y distribución de responsabilidades, de tal forma que existan controles recíprocos entre trabajadores, áreas y/o departamentos, pero que, al mismo tiempo, siempre haya un responsable último de cada proceso identificado como riesgoso para evitar la dilución de la responsabilidad en la organización $^{10}$.

\footnotetext{
${ }^{9}$ En este sentido, ARTAZA VARELA, "Programas de cumplimiento", cit. nota no 7, p. 238, sostiene que, uno de los propósitos de los programas de cumplimiento es compensar la orientación empresarial a la obtención de beneficios, manifestada en presiones a los integrantes de la entidad, bajo la forma de ciertos esquemas de incentivos orientados a la obtención de resultados a corto plazo.

${ }^{10}$ Tal y como sostiene LASCURAÍN SÁNCHEZ, Juan Antonio, "La delegación como mecanismo de prevención y de generación de deberes penales" en: NIETO MARTÍN, Adán (Dir.), Manual de cumplimiento penal en la empresa, Barcelona: Tirant lo Blanch, 2015, pp. 165-185, p. 179, un buen sistema de delegaciones constituye un mecanismo de debido control que podría impedir la responsabilidad penal de la entidad.
} 
Por otra parte, con el fin de supervisar el efectivo funcionamiento del modelo se exige, al menos para las grandes empresas, la existencia de un organismo con poderes autónomos de iniciativa y control respecto de la dirección de la entidad (arts. 6.1.b) D. Lgs. 231, 31 bis 2. $2^{\circ} \mathrm{CP} \mathrm{y} 4^{\circ}$ 1) b) Ley 20.393). Este organismo de control, en caso de existir como un órgano separado de la administración de la entidad, podría estar dirigido por el oficial de cumplimiento o compliance officer o, incluso, podría ser un agente externo e independiente de la entidad ${ }^{11}$. En una línea similar, la regulación chilena exige, como uno de los requisitos mínimos que ha de contener el modelo de prevención de delitos, el nombramiento de un encargado de prevención, designado por la máxima autoridad administrativa de la entidad, con acceso directo a la alta dirección, a la que tendrá que rendir cuentas de su gestión, pero con autonomía financiera y funcional respecto de aquella (art. 4 apdos. 1 y 2 Ley 20.393).

El compliance officer o el encargado de prevención tendría, entre otras funciones, la de gestionar el canal de denuncias o sistema de whistleblowing, que es otro de los contenidos esenciales del programa de cumplimiento, cuya finalidad es la detección de irregularidades o infracciones (arts. 6.2. d) D. Lgs. 231, 31 bis 5. $4^{\circ} \mathrm{CP}$ y $4^{\circ}$ 3) d) Ley 20.393) ${ }^{12}$. Así mismo, el encargado de prevención sería el responsable de actuar en caso de incidencias o inobservancias del programa, comunicándolas, en su caso, a los administradores de la organización o, incluso, reportándolas a la autoridad competente cuando se determine la comisión de un ilícito penal.

Otro elemento común exigido por las tres regulaciones objeto de estudio es la existencia de un sistema interno de sanciones que permita exigir responsabilidad disciplinaria a aquellos miembros de la organización que incumplan las reglas, protocolos, deberes o prohibiciones derivados del programa (arts. 6.2.e) y 7.4.b) D. Lgs. 231,31 bis 5 . $4^{\circ} \mathrm{CP}$ y $4^{\mathrm{o}} .3$ ) d) Ley 20.393). Ahora bien, en este punto la regulación chilena va más allá al exigir que estas obligaciones, prohibiciones y sanciones internas, además de contenerse en los reglamentos internos de la persona jurídica, se incorporen a los contratos de todos los trabajadores, incluidos los de los máximos ejecutivos (art. 4.3) d) II Ley 20.393). Esto sirve, por una parte, para incluir las obligaciones de cumplimiento entre las obligaciones laborales del

\footnotetext{
${ }^{11}$ En este orden de ideas, resulta interesante la propuesta de NIETO MARTÍN, "Problemas fundamentales del cumplimiento", cit. nota $n^{\circ} 2$, p. 43, que apuesta por la externalización e independencia de las personas que diseñan, implantan y supervisan el programa como forma de avanzar en su efectividad. El autor se refiere, en concreto, a la posibilidad de externalizar los canales de denuncia, así como de dejar la supervisión del programa en manos de personas externas a la empresa, tales como entidades que representen los intereses sociales que la actividad de la empresa pone en riesgo; La Fiscalía General del Estado español (en adelante, FGE) también apuesta por la externalización en la gestión del canal de denuncias (Circular 1/2016, sobre la responsabilidad penal de las personas jurídicas conforme a la reforma del código penal efectuada por ley orgánica 1/2015 (en adelante, Circular 1/2016), p. 48.

${ }^{12}$ En relación con el canal de denuncias, las regulaciones española e italiana, a diferencia de la regulación chilena, parecen establecer una obligación general, para todos los miembros de la organización, de informar de los posibles riesgos e incumplimientos al organismo de prevención. Sin embargo, según GARCÍA MORENO, Beatriz, "Whistleblowing y canales institucionales de denuncia", en: NIETO MARTÍN, Adán (Dir.), Manual de cumplimiento penal en la empresa, Barcelona: Tirant lo Blanch, 2015, pp. 205-230, pp. 221-223, pone en duda que pueda existir una obligación genérica de denunciar irregularidades que incumba a todos los miembros de la organización, por no encontrar amparo en la legislación laboral, salvo cuando la obligación de denunciar pueda considerarse implícita en el puesto y, por lo tanto, incluida en el contrato laboral.
} 
NEIRA, Ana María. "La efectividad de los criminal compliance programs como objeto de prueba en el proceso penal".

trabajador y, por otra, para objetivar el control de las autoridades a la hora de determinar si se ha cumplido efectivamente con esta obligación.

En definitiva, es preciso que la entidad tenga un sistema de reacción ante eventuales incumplimientos del programa, los cuales pueden ir desde la mera inobservancia de los protocolos o medidas internas de prevención, hasta la efectiva comisión de actuaciones delictivas en su seno. Para afrontar tales situaciones, la entidad deberá contar, por una parte, con un sistema de denuncias que permita el órgano de control tomar conocimiento de tales incumplimientos y, por otro, con un sistema disciplinario para actuar contra los presuntos infractores, determinados, en su caso, tras la correspondiente investigación intraempresarial $^{13}$.

Por último, y dado que la organización no es un ente estático, como tampoco lo son los riesgos a los que se enfrenta, es preciso gestionar el programa con una visión dinámica, de tal forma que sea sometido a revisiones periódicas, para mantenerlo actualizado respecto de las variaciones que se produzcan respecto del inicial análisis de riesgos penales, ya por incumplimientos o fallos detectados, ya por cambios en la propia organización o en el entorno legal en el que opera (arts. 7.4.a) D. Lgs. 231, 31 bis $5.4^{\circ} \mathrm{CP}$ y $4^{\circ} .4$ ) a) Ley 20.393)).

Pues bien, analizados los requisitos de un programa de cumplimiento eficaz, cabe concluir que la adopción, por la empresa, de un modelo de tales características, exige la consecución de una serie de pasos. En primer lugar, habrá que diseñar correctamente el modelo, considerando, no solo la valoración de los riesgos propios de la actividad del ente, sino también las características específicas de su estructura organizativa. En segundo lugar, es preciso implementar el modelo, adaptando la organización y el comportamiento de sus miembros al mismo, para lo cual puede ser preciso desarrollar programas de capacitación de los trabajadores y, en su caso, acometer ciertos cambios en los procesos de decisión y actuación de la entidad, así como en su estructura directiva y organizativa. Y, en tercer lugar, será preciso desarrollar un proceso continuo de actualización y revisión del modelo ${ }^{14}$.

A la vista de las regulaciones analizadas, lo primero que llama la atención son las enormes similitudes que se observan entre el contenido previsto para tales programas en la Ley chilena, en la italiana y en el CP español, lo cual conduce a concluir que tales legislaciones han bebido de una fuente común en su elaboración, seguramente de la ley italiana, que es

\footnotetext{
13 Sobre las investigaciones internas empresariales, véase NIETO MARTÍN, Adán, "Investigaciones internas", en: NIETO MARTÍN, Adán (Dir.), Manual de cumplimiento penal en la empresa, Tirant lo Blanch: Barcelona, 2015, pp. 231-270.

${ }^{14}$ Siguiendo a GARCÍA CAVERO, Percy, Criminal Compliance, Lima: Palestra Editores, 2014, pp. 27-52, para incorporar un programa de cumplimiento a la empresa deben seguirse los siguientes pasos. En primer lugar, el de formulación, que abarca la identificación de los riesgos, la definición de las medidas de prevención, detección y comunicación y la instauración en la empresa de la estructura propia del programa. En segundo lugar, la implementación, que implica informar a los miembros de la organización sobre el programa, incentivar la vigencia del programa y adoptar medidas que aseguren tal vigencia. Por último, estaría la fase de consolidación y perfeccionamiento, que incluye los protocolos de reacción ante la inobservancia del programa de cumplimiento, las sanciones ante eventuales inobservancias del programa y el mejoramiento del mismo a través de reevaluaciones y revisiones periódicas.
} 


\section{Polít. crim. Vol. 11, No 22 (Diciembre 2016), Art. 5, pp. 467-520. \\ [http://www.politicacriminal.cl/Vol_11/n_22/Vol11N22A5.pdf]}

cronológicamente anterior o de las U.S.S.G. norteamericanas ${ }^{15}$, sin que se aprecien verdaderas especificidades, como cabría esperar en una materia que bien podría estar adaptada a la realidad empresarial y al marco jurídico de cada país, sobre todo, si se toma en consideración que no en todos los Estados las personas jurídicas responden por los mismos delitos. En este sentido, se dice que la ley ha operado como fuente de estandarización en relación con el contenido de los programas de cumplimiento ${ }^{16}$.

Por otra parte, cabe señalar que todas estas disposiciones sobre organización empresarial interna parecen más propias de la legislación mercantil que de un CP. En este sentido, podría resultar técnicamente más correcto, bien regular la responsabilidad penal de las personas jurídicas en una ley especial, como en Italia y Chile, bien diseñar el debido control como una norma penal en blanco, cuyo contenido se complementase con las correspondientes regulaciones mercantiles o administrativas en la materia, según el tipo de persona jurídica, de actividad social, de riesgo delictivo a prevenir etc. Desde luego la solución española, que recoge en el propio $\mathrm{CP}$ este tipo de normas sobre la estructura organizativa de las personas jurídicas, no parece la más adecuada desde el punto de vista de la técnica legislativa.

Otra cuestión que conviene destacar, aun cuando pudiera resultar evidente, es que a mayor precisión de la regulación legal en relación con el contenido de los programas de cumplimiento, mayor seguridad jurídica para las personas jurídicas, tanto en lo relativo a los deberes de control que deben asumir, como en lo relativo a los efectos que la adopción de un modelo de prevención de delitos puede tener en la determinación de su responsabilidad. En este sentido, tal y como afirma Nieto Martín, el Derecho Penal puede servir para aportar seguridad jurídica al sistema interno de prevención, contribuyendo a su formalización a través de la determinación legal de sus elementos básicos ${ }^{17}$.

Ahora bien, también es necesario señalar los riesgos que encierra una regulación legal excesivamente detallada. Si la ley es muy específica en la determinación de los elementos que han de contener los programas de prevención, esto puede suponer una tendencia de las empresas a estandarizar sus medidas de dirección y control, a la vez que se puede dificultar la declaración de responsabilidad penal en relación con aquellas personas jurídicas que

\footnotetext{
15 Esta normativa también se refiere a la necesidad de que la entidad ejerza la diligencia debida en la prevención y detección de conductas criminales y de que promueva una cultura organizativa que incentive las conductas éticas y el compromiso de cumplimiento con la ley (\$8B2.1. (a). U.S.S.G.) Para ello, cabe señalar, muy resumidamente, que la corporación debe adoptar estándares y procedimientos para prevenir y detectar las conductas criminales, implicar a los directivos de alto nivel en el funcionamiento del programa, dar a conocer el programa entre sus miembros desarrollando programas de formación, asegurarse de que el programa es respetado implementando mecanismos de monitoreo y auditoría para detectar conductas criminales, que incluyan sistemas de denuncias anónimos o confidenciales, promover el programa a través de sistemas de incentivos y sanciones adecuados, adoptar medidas razonables para responder apropiadamente a la conducta criminal una vez que es detectada y evaluar periódicamente la efectividad del programa (§8B2.1. (b) U.S.S.G.).

${ }^{16}$ NIETO MARTÍN, Adán, "Fundamentos y estructura de los programas de cumplimiento normativo", en: NIETO MARTÍN, Adán (Dir.), Manual de cumplimiento penal en la empresa, Barcelona: Tirant lo Blanch, 2015, pp. 111-134, esp. 112, se refiere a la ley como fuente de estandarización de la estructura y el contenido de los programas de cumplimiento, refiriéndose, precisamente, al caso de Chile, Italia y España.

${ }^{17}$ NIETO MARTÍN, "Problemas fundamentales del cumplimiento", cit. nota no 2, p. 30.
} 
NEIRA, Ana María. "La efectividad de los criminal compliance programs como objeto de prueba en el proceso penal".

cumplen formalmente con unos requisitos legales de mínimos. Esta situación, además de restar libertad valorativa al órgano judicial, puede inducir a la entidad a desarrollar el programa únicamente hasta donde le resulte económicamente más eficiente, esto es, hasta el mínimo legal exigido, sin preocuparle realmente si, en la práctica, es útil y efectivo en la detección o prevención de los delitos ${ }^{18}$. Por otra parte, el sistema de certificaciones, al que más adelante se aludirá, si no se entiende correctamente, podría agravar esta situación.

Para valorar cuando una organización cuenta con un modelo de prevención y detección de delitos eficaz, es preciso hacerlo desde una perspectiva antiformalista, esto es, sin atender única y exclusivamente al modelo propuesto por la regulación legal e intentando determinar si, efectivamente, la entidad actuó con la diligencia debida en la evitación del delito cometido. En este sentido, la $\mathrm{FGE}^{19}$ señala que, la clave para valorar la eficacia del programa de prevención radica, sobre todo, en la importancia que tal modelo tiene en la toma de decisiones de sus dirigentes y empleados, y en qué medida es una verdadera expresión de su cultura de cumplimiento y de su compromiso de disuadir conductas ilegales, más allá de su conformidad formal con las condiciones y requisitos que establece la Ley. Por su parte, el Ministerio Público chileno (en adelante MP de Chile) ${ }^{20}$, en la misma línea, señala que el hecho de cumplir la empresa formalmente con todos los requisitos legales del art. $4^{\circ}$ Ley 20.393 "no implica que ésta haya implementado el modelo real, eficaz o idóneamente, lo cual será siempre objeto de investigación y prueba”.

Esta antiformalismo se refleja claramente en la literalidad de la regulación chilena, que concibe los programas de cumplimiento como un indicador del efectivo cumplimiento de los deberes de supervisión y dirección de la entidad (art. $3^{\circ}$ III Ley 20.393), circunstancia que, en principio, cabrá acreditar también por otros medios. Por lo tanto, aunque la empresa no haya adoptado un modelo de prevención como el propuesto por la ley, de ahí no cabe derivar, automáticamente, que la comisión del delito fue consecuencia del incumplimiento de los deberes de supervisión y de dirección por parte de la persona jurídica, lo cual, en todo caso, deberá ser acreditado la acusación ${ }^{21}$.

En el caso de pequeñas y medianas empresas (en adelante, PYMES), con mayor motivo, no cabe exigir un cumplimiento estricto de los requerimientos legales sobre el contenido de los programas de prevención de delitos. Así pues, aunque a tales empresas, también es preciso exigirles medidas de prevención de delitos y un compromiso claro con el cumplimiento de la legalidad, no cabe requerirles el mismo grado de formalización en los instrumentos de prevención y detección de delitos que a las empresas grandes, ya que podría resultar desproporcionado en relación con la escasa complejidad de su estructura organizativa, con su tamaño y con el volumen de sus recursos ${ }^{22}$.

\footnotetext{
${ }^{18}$ HUFF, Kevin, "Note: The Role of Corporate "compliance" Programs in Determining Corporate Criminal Liability: A Suggested Approach”, Columbia Law Review, no 96 (1996), pp. 1252-1298, p. 1275.

${ }^{19}$ FGE, Circular 1/2016, p. 52.

${ }^{20}$ MP de Chile, Oficio FN no 440/2010, p. 7.

21 MP de Chile, Oficio FN no 440/2010, p. 7; VAN WEEZEL DE LA CRUZ, Alex, "Contra la responsabilidad penal de las personas jurídicas", Polít. Crim., vol. 5, no 9 (2010), pp. 114-142, pp. 138-139, en: http://www.politicacriminal.cl/Vol_05/n_09/Vol5N9A3.pdf [visitado el 12.07.2016].

22 \$B2.1 [Application note 2(A) y 2(C)] U.S.S.G.
} 
Dado que el tamaño o la complejidad organizativa de la entidad también son factores a tener en cuenta a la hora de determinar las medidas de organización y control precisas para mantener los riesgos penales en niveles jurídicamente aceptables, es habitual que la regulación establezca exigencias atenuadas o medidas de supervisión menos estrictas para aquellas empresas de pequeñas dimensiones o cuyo volumen de actividad es menor. En este sentido, las regulaciones española, chilena e italiana contemplan la especificidad de las personas jurídicas de menor tamaño, señalando que, en las entidades de pequeñas dimensiones, las funciones de supervisión que, habitualmente, deben ser asumidas por un órgano con poderes autónomos de control, podrán ser asumidas directamente por el órgano de administración o de dirección (arts. 31 bis 3 CP, 6.4 D. Lgs. 231 y 4 1. B) II Ley 20393)

A pesar de la señalada salvedad en relación con la separación entre la administración y el encargado de prevención, en las leyes analizadas se mantienen, sin embargo, en relación con las PYMES, el resto de los requisitos de estructura y contenido de cualquier modelo de organización y gestión. Sin embargo, según la FGE, a pesar de existir esa determinación legal,

“estas pequeñas organizaciones podrán (...) demostrar su compromiso ético mediante una razonable adaptación a su propia dimensión de los requisitos formales del apartado 5, que les permita acreditar su cultura de cumplimiento normativo, más allá de la literalidad del precepto y en coherencia con las menores exigencias que estas sociedades tienen también desde el punto de vista contable, mercantil y fiscal",23.

\subsection{Los requisitos de un programa de cumplimiento eficaz.}

El CP español emplea el adjetivo "eficaces" para referirse a las medidas de prevención y descubrimiento de delitos como circunstancia atenuante (art. 31 quáter d) $\mathrm{CP}$ ), mientras que señala como circunstancia que eximiría a la persona jurídica de responsabilidad, el haber adoptado y ejecutado "eficazmente" un modelo de organización y gestión "adecuado" para prevenir delitos o para reducir el riesgo de su comisión (arts. 31 bis $2.1^{\circ}$ y 31 bis $4 \mathrm{CP}$ ).

Igualmente, en otras legislaciones, así como en los estudios doctrinales sobre la materia, resulta habitual la referencia a la eficacia de las medidas de prevención delictiva. De ahí la extendida denominación anglosajona que se refiere a los programas de prevención delictiva como effective compliance programs ${ }^{24}$. Por su parte, la regulación chilena también se refiere al establecimiento de métodos para la aplicación efectiva del modelo de prevención de delitos (art. $4^{\circ} .4$. a) Ley 20.393), mientras que la ley italiana habla de la necesidad de que se haya adoptado y actuado eficazmente, antes de la comisión del hecho, un modelo de organización y gestión idóneo para prevenir los delitos de la especie del que se haya cometido, como requisito para que la entidad quede exenta de responsabilidad (arts. 6.1.a) y 7.2 D. Lgs. 231).

Estas referencias a la eficacia indican que no es suficiente con que la persona jurídica

\footnotetext{
${ }^{23}$ FGE, Circular 1/2016, p. 50.

${ }^{24}$ Así pues, las guías americanas para dictar sentencias frente a organizaciones disponen la necesidad de que las organizaciones, para ver reducida su culpabilidad por la comisión de delitos en su seno, cuenten con un "effective compliance and ethics program" (\$8B2.1. U.S.S.G).
} 
NEIRA, Ana María. "La efectividad de los criminal compliance programs como objeto de prueba en el proceso penal".

cuente con el diseño, sobre el papel, de un programa de cumplimiento, sino que tal modelo habrá de ser idóneo para reducir los específicos riesgos delictivos propios de su actividad a niveles jurídicamente aceptables, habrá de estar adaptado a la estructura organizativa y al tamaño de la entidad y, además, habrá de estar implementado de forma efectiva en la estructura societaria. Esto último significa que la forma organizativa y los procesos de la entidad, tanto a nivel estratégico como a nivel operativo, han de responder a los principios y protocolos del modelo, haciendo partícipes de su efectiva aplicación a todos los miembros de la organización.

En definitiva, para valorar la eficacia del programa de cumplimiento hay que tomar en consideración ciertas cuestiones que pasamos a analizar.

a) En primer lugar, cabe señalar que la eficacia que se exige para los programas de cumplimiento normativo es una eficacia relativa, en el sentido de que la comisión de un delito no implica necesariamente la ineficacia del sistema ${ }^{25}$. Por lo tanto, eficacia no puede asimilarse a infalibilidad en la prevención y evitación de los delitos. De ahí que un factor importante para valorar tales programas sea, precisamente, su capacidad de detectar las infracciones que se cometen y de reaccionar adecuadamente ante tales fallas ${ }^{26}$.

Hay que tener en cuenta que los programas de cumplimiento no pueden ni pretenden neutralizar absolutamente el riesgo de comisión de delitos siendo exigible, únicamente, que sirvan para gestionar los riesgos de comisión de infracciones, de tal forma que estos se mantengan en niveles jurídico-penalmente aceptables ${ }^{27}$. A la organización se le exige, en definitiva, que se establezca y opere de tal forma que los riesgos penales asociados a su actividad estén adecuadamente controlados, desplegándose la diligencia debida para

\footnotetext{
${ }^{25}$ En este sentido, la FGE, Circular 1/2016, pp. 53-54, afirma que, cualquier programa de prevención, por eficaz que sea, soporta un cierto riesgo residual de comisión de delitos; En el mismo sentido, en las guías americanas para dictar sentencias frente a organizaciones se dispone lo siguiente: "the failure to prevent or detect the instant offense does not necessarily mean that the program is not generally effective in preventing and detecting criminal conduct" (\$8B2.1 (a) U.S.S.G.).

${ }^{26}$ GÓMEZ-JARA DÍEZ, Carlos, "La culpabilidad de la persona jurídica", en: BAJO FERNÁNDEZ, Miguel; FEIJOO SÁNCHEZ, Bernardo José; GÓMEZ-JARA DÍEZ, Carlos, Tratado de responsabilidad penal de las personas jurídicas. $2^{\mathrm{a}}$ ed. Adaptado a la Ley 1/2105, de 30 de marzo, por la que se modifica el Código Penal, Navarra: Aranzadi, 2016, pp. 143-219, p. 189, sostiene que "la persona jurídica que detecta la comisión de un hecho delictivo en su interior, lo reporta a las autoridades y coopera mediante la aportación de pruebas que esclarecen las responsabilidades es una persona jurídica cumplidora de la legalidad".

${ }^{27}$ En palabras de ARTAZA VARELA, Osvaldo, La empresa como sujeto de imputación de responsabilidad penal. Fundamentos y límites, Marcial Pons: Madrid, 2013, p. 360, no se trata de las medidas de cuidado eviten toda clase de conductas delictivas, sino de que la empresa controle la peligrosidad de su propio ámbito de organización; Tal y como afirma BOCK, "Compliance y deberes de vigilancia", cit. nota $\mathrm{n}^{\circ} 1$, pp. 111 y ss., estos programas no pretenden suprimir la actividad empresarial en razón de los riesgos que necesariamente comporta, sino que lo que buscan es implementar medidas que mantengan la peligrosidad de la actividad empresarial en niveles social y jurídicamente permitidos; En la misma línea, GÓMEZ-JARA DÍEZ, "La culpabilidad de la persona jurídica" cit. nota $\mathrm{n}^{\circ} 26$, p. 188 , afirma que no se puede exigir a la persona jurídica que no genere ningún tipo de riesgos, dado que el desempeño de la actividad empresarial conlleva per se un cierto riesgo, por eso, lo exigible por el Derecho Penal será que dicho riesgo no supere el ámbito de lo permitido).
} 
minimizar el riesgo de comisión de ilícitos penales ${ }^{28}$. Por eso, si la organización cumple con tales deberes, a través de la implementación efectiva de un programa de prevención de delitos eficaz, pero, a pesar de ello, alguno de sus empleados comete una infracción penal, la entidad no debería responder penalmente, en tanto que, al haber establecido mecanismos de dirección, supervisión y control adecuados, habría cumplido con sus deberes de garante en relación con los bienes jurídicos que pone en peligro con su actividad.

b) En segundo lugar, se debe partir de que, aun cuando existen elementos comunes a cualquier programa de cumplimiento, es clave que el modelo se adapte a las características de cada organización y a los específicos riesgos de su actividad. En este sentido, otro aspecto relevante para valorar la eficacia de los programas de cumplimiento radica en el hecho de que el modelo responda a la idiosincrasia de la organización, esto es, que sea idóneo para la organización en que se va a implementar. Por consiguiente, no existe un programa de cumplimiento de validez general, sino que el programa, para ser efectivo, debe adecuarse a las características estructurales de la entidad, a los riesgos propios de su actividad y al entorno legal en que opera ${ }^{29}$. En esta línea, se afirma que "un modelo estereotipado de cumplimiento que no atiende a las peculiaridades organizativas de cada concreta organización es, por definición, ineficaz"30.

En este sentido, se debe partir de la base de que los riesgos que debe afrontar cada tipo de empresa difieren en función de su estructura organizativa, de su tamaño y, sobre todo, de la naturaleza de su actividad. Por ejemplo, los controles necesarios en una empresa donde las decisiones se toman de forma descentralizada, no son iguales que los que demanda una empresa en la que hay una jerarquía vertical fuerte, como tampoco son comparables los riesgos a prevenir en una empresa multinacional y en una que limita su actividad al territorio de un Estado, ni los que enfrenta una entidad financiera y la industria farmacéutica.

La necesidad de valorar la idoneidad del modelo para prevenir los específicos riesgos de la organización en la que se implementa, en ocasiones va a dificultar y a tecnificar la prueba de su eficacia en el proceso penal, impidiendo objetivarla o estandarizarla. En este sentido, para valorar si se asumieron riesgos excesivos en el desarrollo de una determinada

\footnotetext{
${ }^{28}$ GÓMEZ-JARA DÍEZ, Carlos, "Fundamentos de la responsabilidad penal de las personas jurídicas", en: BAJO FERNÁNDEZ, Miguel; FEIJOO SÁNCHEZ, Bernardo José; GÓMEZ-JARA DÍEZ, Carlos, Tratado de responsabilidad penal de las personas jurídicas. $2^{\mathrm{a}}$ ed. Adaptado a la Ley 1/2105, de 30 de marzo, por la que se modifica el Código Penal, Navarra: Aranzadi, 2016, pp. 89-119, pp. 105-107, construye una teoría del delito de la persona jurídica, acudiendo a equivalentes funcionales. En este sentido, sostiene que la tipicidad objetiva del injusto típico de la persona jurídica sería el defecto de organización, esto es, la organización de la entidad de forma que se superen los niveles de riesgo permitido, la tipicidad subjetiva o el dolo de la persona jurídica consistirían, por su parte, en el conocimiento organizativo de la persona jurídica sobre tal asunción excesiva de riesgos $\mathrm{y}$, por último, su culpabilidad se fundamentaría en la cultura empresarial de incumplimiento de la legalidad o en una defectuosa cultura de compliance.

${ }^{29}$ Cfr. ARTAZA VARELA, "Programas de cumplimiento", cit. nota n ${ }^{\circ}$ 7, p. 240.

${ }^{30}$ GALLEGO SOLER, José Ignacio, "Criminal compliance y proceso penal: reflexiones iniciales", en: MIR PUIG, Santiago; CORCOY BIDASOLO, Mirentxu; GÓMEZ MARTÍN, Víctor (Dirs.); HORTAL IBARRA, Juan Carlos; VALIENTE IBÁÑEZ, Vicente (Coords.), Responsabilidad de la empresa y compliance. Programas de prevención, detección y reacción penal, Montevideo-Buenos Aires: B de F, 2014, pp. 195-229, p. 205.
} 
NEIRA, Ana María. "La efectividad de los criminal compliance programs como objeto de prueba en el proceso penal".

actividad, pueden ser necesarios conocimientos extrajurídicos, de ingeniaría, medicina, dirección empresarial, auditoría etc., aun cuando será el juez el que, en último término, determine si se ejerció el debido control ${ }^{31}$.

c) En tercer lugar, hay que insistir en que un programa de cumplimiento, para ser eficaz, ha de estar en funcionamiento y ha de ser dinámico, por lo que no es suficiente con que se diseñe correctamente, sino que además ha de implementarse de forma efectiva en la organización y actualizarse periódicamente. Desde esta perspectiva, otra de las claves para que un programa de cumplimiento penal pueda llegar a tener eficacia eximente en relación con la responsabilidad de la persona jurídica, radica en que se encuentre efectivamente implementado en la estructura y en las dinámicas de la organización.

Por lo tanto, no es suficiente con el adecuado diseño del programa, sino que, además, es preciso establecer un sistema de incentivos y sanciones coherente con los principios y reglas de actuación definidos en el mismo, instaurar protocolos de minimización o prevención de riesgos delictivos para formalizar los subprocesos en los que la comisión de infracciones es más probable, reaccionar de forma adecuada ante eventuales incumplimientos de las normas del programa, sancionando a los responsables y, en su caso, reportando a la autoridad la comisión de delitos y, en definitiva, adaptar la propia estructura organizativa de la entidad a los principios y protocolos definidos en el programa ${ }^{32}$. De esta forma no sólo se estará ante un programa idóneo ex ante para prevenir y detectar los riesgos delictivos de la entidad, sino que también se podrá afirmar su efectiva vigencia en la organización $^{33}$.

La implementación del modelo supone, en definitiva, adaptar el funcionamiento de la entidad al programa. Para ello es necesario, por una parte, establecer las estructuras organizativas adecuadas, tales como el cargo del encargado de prevención, los canales de comunicación interna apropiados, unos canales de denuncia accesibles y confiables para los trabajadores etc. Y, por otra parte, es menester adaptar el comportamiento de los miembros de la organización al programa, para lo cual resultan esenciales los sistemas de sanciones e incentivos y los instrumentos de información y capacitación de los empleados y directivos.

Así mismo, para adoptar una política de cumplimiento penal eficaz resulta muy relevante el tono de la alta dirección (el conocido en terminología anglosajona como tone from the top), esto es, la tónica marcada por los máximos responsables de la entidad en lo que se refiere al cumplimiento normativo y a la actuación ética de la organización, que debe ser adecuada,

\footnotetext{
${ }^{31}$ Cfr. NIETO MARTÍN, "Fundamentos y estructura”, cit. nota no 16, p. 116-117.

32 En este sentido, COCA VILA, Ivó, “¿Programas de cumplimiento como forma de autorregulación regulada?”, en: SILVA SÁNCHEZ, Jesús María (Dir.); MONTANER FERNÁNDEZ, Raquel (Coord.), Criminalidad de empresa y compliance. Prevención y reacciones corporativas, Barcelona: Atelier, 2013, pp. 43-76, p. 62, sostiene que, a pesar de que la regulación no establece criterios para determinar la eficacia de los compliance, parece claro que la misma dependerá tanto de su configuración inicial como de su aplicación y ejecución adecuada.

${ }^{33}$ Según GÓMEZ-JARA DÍEZ, “La culpabilidad de la persona jurídica” cit. nota no 26, p. 188, que “el término eficaz debe interpretarse como eficacia ex ante - en lo relativo a la tipicidad objetiva- y como vigencia -en lo relativo a la culpabilidad-".
} 
seria, creíble y convincente ${ }^{34}$. Para ello debe enviarse un mensaje continuo a todos los miembros de la organización, sobre cuál debe ser la cultura o el estándar ético con el que han de operar los miembros de la organización y sobre cuán serios y rigurosos son los controles a los que será sometida su actuación. Con esa comunicación interna, que desciende verticalmente a través de la jerarquía empresarial, ha de determinarse de forma clara y contundente que la legalidad no es sólo un límite a la actuación de la empresa, sino parte integrante de la cultura organizacional que, por lo tanto, ha de gestionarse a nivel estratégico.

Para gestionar el riesgo delictivo de forma eficiente es necesario, por lo tanto, generar una cultura organizacional que tienda a la observancia del ordenamiento jurídico ${ }^{35}$. Pero adoptar una cultura cumplidora de la legalidad no es suficiente, es necesario poder probarlo en juicio, para lo cual, como se argumentará más adelante, resultará esencial contar con el testimonio de aquellos sujetos encargados de fomentar esta cultura, así como con el de aquellos otros que ven condicionadas sus funciones en la organización por el modelo de cumplimiento normativo.

En definitiva, de la comisión de un delito en nombre y por cuenta de una persona jurídica no se deriva automáticamente su responsabilidad penal, sino que será preciso determinar si la entidad tenía efectivamente implementado un programa de cumplimiento penal idóneo para prevenir y detectar la comisión de ilícitos de la naturaleza del supuestamente perpetrado en su seno ya que, sólo de esta forma, podrá determinarse si la entidad empleó la diligencia debida para cumplir con las normas que regulan su responsabilidad penal.

\section{Las consecuencias de tener implementado un modelo de prevención de delitos eficaz antes de la comisión del delito.}

La relevancia de los compliance como objeto de prueba en el proceso viene determinada por los efectos que la ley apareja a su efectiva implementación, tanto en la determinación de la responsabilidad penal de las personas jurídicas, como en la individualización de las penas que, en su caso, les correspondan si resultan condenadas.

Así pues, en Chile, la existencia y la implementación de un programa de cumplimiento eficaz para prevenir los delitos de la especie del cometido supone una presunción a favor del adecuado cumplimiento de los deberes de dirección y supervisión (art. $3^{\circ}$ III Ley 20.393), que implicaría la atipicidad o la irrelevancia penal de la conducta de la persona jurídica. En la misma línea, la regulación italiana dispone que, en todo caso, se excluye la inobservancia de las obligaciones de dirección y vigilancia, si el ente, antes de la comisión del delito, ha adoptado e implementado eficazmente un modelo de organización, gestión y control idóneo para prevenir delitos de la especie del que presuntamente se ha perpetrado (art. 7. 2 D. Lgs. 231). Se trata, en este caso, de presunciones legales, es decir, aquellas en las que la inferencia entre el hecho indicio y el hecho presupuesto aparece establecida en la propia ley.

\footnotetext{
${ }^{34}$ Sobre la importancia de que la alta dirección se involucre en las labores de compliance, véanse las reflexiones de ARTAZA VARELA, "Programas de cumplimiento", cit. nota no 7, pp. 246 y 253-256.

${ }^{35}$ Cfr. ARTAZA VARELA, "Programas de cumplimiento", cit. nota $n^{\circ} 7$, pp. 246.
} 
NEIRA, Ana María. "La efectividad de los criminal compliance programs como objeto de prueba en el proceso penal".

Con las referidas presunciones se facilita que la entidad pueda probar, en su descargo, que cumplió con sus obligaciones de dirección y vigilancia, estableciéndose normativamente que la entidad que cuenta con un modelo de prevención de delitos eficaz, no omitió los controles debidos sobre sus empleados en el caso concreto $\mathrm{y}$, por lo tanto, no debe responder por las actuaciones de aquellos. Así pues, ante la imposibilidad para la defensa de practicar una prueba diabólica sobre el hecho negativo de que, en el caso concreto, no se omitió el control debido, la estrategia defensiva de la entidad se centrará en acreditar la efectiva implementación de un programa de cumplimiento efectivo en los términos que determina la ley.

De acuerdo con la regulación sobre la materia vigente en España, en el supuesto de que fuese un subordinado el autor del delito base, un programa de cumplimiento eficaz podría servir para que la entidad quedase exenta de responsabilidad (art. 31 bis 4) CP). Por otra parte, parece lógico pensar que si la entidad implementa medidas eficaces para prevenir y detectar delitos, aun cuando no se ajusten exactamente a los requisitos legales establecidos en el CP, tales medidas preventivas podrían servir como indicio de que, en el caso concreto, no hubo un incumplimiento grave de los deberes de supervisión, vigilancia y control y que, por lo tanto, el delito cometido por sus miembros no es imputable a la persona jurídica por faltar ese requisito típico (art. 31 bis 1 b) CP). Ahora bien, esta relación o enlace lógico entre la efectividad de las medidas de prevención delictiva y el cumplimiento de los deberes de control no aparece explícitamente recogido en la Ley española, sino que queda a discrecionalidad del intérprete tomarla en consideración. Se trataría, en este caso, de una presunción judicial.

La principal diferencia entre las regulaciones italiana y española, muy similares entre sí, y la chilena, que se aleja de las otras dos en este punto, radica en que, en las dos primeras la inobservancia de las obligaciones de dirección y vigilancia sólo se establece como elemento constitutivo de la responsabilidad de la persona jurídica y, por lo tanto, como parte de la ofensa imputable a la entidad, para el caso de que el delito haya sido cometido por un subalterno, pero no cuando quien delinque es un sujeto "apical"

En España e Italia, cuando el delito ha sido cometido por un sujeto en posición apical, la existencia y efectiva implementación de un programa idóneo para prevenir los delitos de la especie del presuntamente cometido constituye tan sólo uno de los requisitos que integran la eximente de responsabilidad para la persona jurídica. Por lo tanto, su acreditación, siendo necesaria, no es suficiente para que la entidad quede exenta de responsabilidad por los delitos cometidos por sus dirigentes. Será necesario, a tal fin, acreditar, así mismo, el resto de las exigencias previstas en los arts. 6.1 D. Lgs. 231 y 31 bis $2 \mathrm{CP}$, que se configuran como requisitos acumulativos. En concreto, habrá que probar que el organismo encargado

\footnotetext{
${ }^{36}$ El término apical es empleado por la regulación italiana para referirse a aquellos sujetos que desarrollan funciones de representación, administración o dirección del ente o respecto de alguna de sus unidades organizativas con autonomía, ya funcional, ya financiera, así como para quienes ejercen la gestión o el control de la entidad de facto. Aunque en castellano no es un término comúnmente empleado, se utilizará en este artículo para referirse a los administradores, representantes legales, directivos o dirigentes de la organización, así como a aquellos que ejercen las funciones decisorias o de organización y control dentro de la entidad, para distinguirlos de los subalternos o subordinados a aquéllos. El vocablo es definido por la RAE, Diccionario, $23^{\circ}$ ed., 2014, como "perteneciente o relativo a un ápice o punta".
} 
de supervisar el programa ejerció debida y suficientemente sus funciones y que el dirigente que delinquió lo hizo eludiendo fraudulentamente las medidas de control de la organización, es decir, engañando al encargado de prevención.

Siguiendo con los efectos ligados a la adopción de un modelo eficaz de prevención de delitos, se aprecia que el programa de cumplimiento, adoptado con posterioridad a la comisión del delito, pero antes de la celebración del juicio, serviría para atenuar la pena de la entidad (arts. 12.2.b) D. Lgs. 231, 31 quater d) CP, 6. 3) Ley 20.393). Esta reducción de la pena se aplicaría tanto al montante de la multa como a la duración o intensidad del resto de penas restrictivas de derechos, cuya imposición podría, incluso, llegar a evitarse $^{37}$.

Por último, en la adopción de medidas cautelares contra societatem o de medidas preventivas dirigidas a neutralizar los riesgos de reincidencia y de reiteración delictiva, la existencia de un programa de cumplimiento eficaz también debe ser objeto de valoración, ya que al no concurrir el periculum in mora o periculum in libertatis, consistente en el riesgo de que, en espera del juicio penal, se reiteren las conductas delictivas, tales medidas podrían devenir innecesarias, y por ende su adopción se reputaría desproporcionada.

En los Estados Unidos, las U.S.S.G. o guías para dictar sentencias establecen los requisitos que ha de tener un programa de cumplimiento eficaz para ser tomado en consideración a los efectos de calcular el índice de culpabilidad de la persona jurídica, del que dependerá su pena, en caso de resultar condenada ${ }^{38}$. Sin embargo, la práctica pone de manifiesto que, en la mayor parte de los casos, no se abre juicio oral ni se dictan sentencias de condena frente a las personas jurídicas, porque la Fiscalía alcanza acuerdos con las corporaciones investigadas o acusadas en una fase previa ${ }^{39}$. En este contexto, la existencia o la adopción de un programa de prevención de delitos eficaz sirve, básicamente, como elemento para negociar un acuerdo con la fiscalía, ya que tales programas se contemplan en los Principles of Federal Prosecution of Business Organizations, como factor a tener en cuenta para

\footnotetext{
${ }^{37}$ Según SILVA SÁNCHEZ, Jesús María, "La responsabilidad penal de las personas jurídicas en Derecho español”, en: SILVA SÁNCHEZ, Jesús María (Dir.); MONTANER FERNÁNDEZ, Raquel (Coord.) Criminalidad de empresa y Compliance. Prevención y reacciones corporativas, Barcelona: Atelier, 2013, pp. 15-42, p. 33, la existencia de medidas eficaces para prevenir los delitos que pudieran cometerse en el futuro, independientemente de que se hayan adoptado antes o después de la comisión del delito, podría implicar que la imposición de penas restrictivas de derechos, distintas de la multa, fuese considerada innecesaria, por no apreciarse la necesidad, requerida para la imposición de tales sanciones, de prevenir la continuidad delictiva; En la misma línea, DOPICO GÓMEZ-ALLER, Jacobo, "Responsabilidad de personas jurídicas", Memento Experto. Reforma Penal 2010. Ley Orgánica 5/2010, Madrid: Francis Lefebvre, 2010, pp. 11-38, p. 24, sostiene que un programa de cumplimiento suficiente e idóneo para evitar la comisión de futuros delitos tendría el efecto de neutralizar la necesidad de imponer penas interdictivas, salvo la de intervención judicial, que se podría establecer con la finalidad de supervisar la correcta implantación de dichas medidas.

38 \$8B2.1. U.S.S.G

${ }^{39}$ Hay que tener en cuenta que, en aquel país, entre un 90 y $95 \%$ de los casos no llegan a juicio, resolviéndose a través de acuerdos con la Fiscalía, denominados guilty pleas, que aparecen regulados en la regla 11 de las Federal Rules of Criminal Procedure. Estos datos, pueden consultarse, desagregados por Distritos, Circuitos y Estados en las estadísticas de la United States Sentencing Commission, disponible en: http://www.ussc.gov/research-and-publications/federal-sentencing-statistics/federal-sentencing-statisticsdistrict-circuit-state [visitado el 02.06.2015].
} 
NEIRA, Ana María. "La efectividad de los criminal compliance programs como objeto de prueba en el proceso penal".

decidir si acusar o no formalmente a la corporación ${ }^{40}$. Aunque la Fiscalía americana indica que la existencia del programa no es suficiente, por si sola, para justificar una decisión de no presentar cargos frente a la entidad, resulta innegable que, en la práctica, es un factor determinante.

De hecho, seguramente, el efecto más importante que producen estos programas en Estados Unidos es el pre-procesal, consistente en evitar o diferir la presentación de cargos penales. Las corporaciones investigadas por la comisión de un delito negocian acuerdos con la Fiscalía en los que se comprometen, bien a adoptar un programa de cumplimiento, bien a mejorar el programa con el que cuentan, recibiendo a cambio un compromiso del Fiscal de diferir (Deferred Prosecution Agreements) o de renunciar (Non-Prosecution Agreements) a su persecución penal, evitando así la mala publicidad que habitualmente se deriva de un proceso penal público y el estigma propio de las condenas penales. También la regulación chilena contempla esta posibilidad al prever la suspensión condicional del procedimiento, pudiendo exigirse a la entidad, entre otras condiciones, la implementación de un programa de prevención delictiva (art. 25.4 Ley 20.393).

Pues bien, estas vías alternativas al proceso penal, según Nieto Martín, serían las más adecuadas para que las empresas incorporasen programas de cumplimiento penal a su estructura organizativa, señalando el autor que "la suspensión del proceso o los acuerdos procesales con las personas jurídicas a cambio de que mejoren su organización interna deberían ser, salvo en el caso de empresas reincidentes, la vía natural de incorporar el compliance al Derecho penal"41.

En cualquier caso, como cuestión de política criminal, y para asegurar el efecto de prevención general que está llamado a desplegar el Derecho Penal, es preciso sostener que, las personas jurídicas que ejercieron sus funciones de control y prevención con el grado de cuidado, diligencia y pericia que, razonablemente, hubiera ejercido una entidad prudente en circunstancias análogas, no deberá responder penalmente, ya sea porque no se presenten cargos en su contra, ya sea porque resulte absuelta tras la celebración del debido proceso penal $^{42}$.

\section{Cómo acreditar procesalmente la eficacia de un programa de cumplimiento penal.}

\subsection{La relevancia de los criminal compliance como objeto de prueba.}

40 9.28.800 Principles of Federal Prosecution of Business Organizations, disponible en: https://www.justice.gov/usam/usam-9-28000-principles-federal-prosecution-business-organizations [visitado el 21.04.2016].

${ }^{41}$ NIETO MARTÍN, "Problemas fundamentales del cumplimiento", cit. nota no 2, p. 49.

${ }^{42}$ Según GÓMEZ-JARA DÍEZ, "La culpabilidad de la persona jurídica” cit. nota n ${ }^{\circ}$ 26, p. 188, si la persona jurídica cumple con sus obligaciones derivadas de ser un buen ciudadano corporativo, el Estado no tendrá nada que reprocharle y deberá renunciar a la imposición de una pena. Castigar a una entidad cumplidora, además de cuestionar la justicia del sistema, sería contraproducente desde el punto de vista político-criminal. 
La Circular 1/2011, dictada por la FGE, relativa a la responsabilidad de las personas jurídicas, resta importancia a la implementación de los programas de cumplimiento en la determinación de la responsabilidad de los entes colectivos. En este sentido, sostiene que:

"lo importante será acreditar (...) que las personas físicas a las que se refiere la norma cometieron el delito en las circunstancias" referidas en la norma, a lo que añade que "si bien es cierto que las compliance guide pueden orientar su forma de actuar en el seno de la corporación, tal extremo resulta circunstancial, por cuanto en el proceso penal se tratará, como siempre, de efectuar un juicio sobre la conducta de los individuos a partir de parámetros de imputación penal referidos a conductas humanas, con independencia de que las mismas obedezcan a un eventual sistema de autorregulación o a la personal forma de hacer del individuo" 43 .

De esta forma, la Fiscalía española subestima el valor de los programas de cumplimiento para determinar la responsabilidad penal de las personas jurídicas $\mathrm{y}$, por ende, aboga por una suerte de irrelevancia de los mismos como objeto de prueba en el proceso penal frente al ente. Si lo relevante para enjuiciar a las personas jurídicas es, exclusivamente, determinar cómo han actuado las concretas personas físicas que integran la organización, independientemente de la existencia y del contenido del programa de cumplimiento vigente en la entidad, las pruebas que pretendan practicarse para acreditar este último extremo resultarían impertinentes, por su desconexión con el objeto procesal e inútiles como parte de la estrategia de defensa de la entidad.

Ahora bien, en contra de la irrelevancia de los programas de compliance como prueba cabe esgrimir, por una parte, que los mismos resultan útiles para determinar en qué medida la entidad ha cumplido con los deberes de supervisar, vigilar y controlar la actividad de sus miembros, manteniendo los riesgos de su actividad en niveles jurídico-penalmente aceptables, lo cual podría determinar la ausencia de culpabilidad de la entidad ${ }^{44}$ o, incluso, la atipicidad de su conducta, sirviendo el programa de cumplimiento como un indicio de que, en el caso concreto, no ha tenido lugar un incumplimiento grave en sus deberes de control $^{45}$. En este sentido, el MP chileno señala que la responsabilidad penal de la persona jurídica es consecuencia del cumplimiento o incumplimiento imperfecto de los deberes de dirección y supervisión de la entidad, de lo que se deriva que la efectiva adopción e implementación del modelo de prevención siempre será objeto de investigación y prueba ${ }^{46}$.

\footnotetext{
${ }^{43}$ FGE, Circular 1/2011, p. 49.

${ }^{44}$ En este sentido, entiende GÓMEZ-JARA DÍEZ, "La culpabilidad de la persona jurídica”, cit. nota n 26, p. 187, que "el hecho de que en una persona jurídica tenga plena vigencia un programa de cumplimiento eficaz en el momento de cometerse el hecho delictivo simboliza una disposición jurídica determinada, una cultura de cumplimiento de la legalidad" que convierte su conducta en irreprochable.

${ }^{45}$ En este sentido, sostiene GÓMEZ-JARA DÍEZ, Carlos, "El injusto típico de la persona jurídica (tipicidad)" en: BAJO FERNÁNDEZ, Miguel; FEIJOO SÁNCHEZ, Bernardo José; GÓMEZ-JARA DÍEZ, Carlos, Tratado de responsabilidad penal de las personas jurídicas. $2^{\mathrm{a}}$ ed. Adaptado a la Ley 1/2105, de 30 de marzo, por la que se modifica el Código Penal, Navarra: Aranzadi, 2016, pp. 121-141, p. 127, que el injusto propio de la persona jurídica viene dado por el defecto de organización, que ha generado un riesgo por encima del permitido, el cual se ha materializado en un resultado lesivo concreto; Por su parte, PIÑ ROCHEFORT, Juan Ignacio, Modelos de prevención de delitos en la empresa, Chile: Abeledo Perrot, 2012, p. 7, entiende que la existencia de un modelo de prevención de delitos eficaz implica la atipicidad de la conducta.

${ }^{46}$ MP de Chile, Oficio FN n 440/2010, p.7.
} 
NEIRA, Ana María. "La efectividad de los criminal compliance programs como objeto de prueba en el proceso penal".

Y, en una línea similar, el TS español entiende que "el defecto estructural en los modelos de gestión, vigilancia y supervisión constituye el fundamento de la responsabilidad del delito corporativo",47.

Adicionalmente, tal y como se indicó en el epígrafe anterior, la implementación de un modelo de organización y gestión eficaz para prevenir delitos se muestra relevante para decretar las necesidades de prevención especial de la persona jurídica, de tal forma que será tomada en consideración, tanto en las decisiones relativas a la adopción de medidas cautelares, como en la determinación de las eventuales penas que se le impongan de resultar condenada.

Determinados los efectos derivados de la efectiva implementación de un programa de cumplimiento penal para la determinación de la responsabilidad de las personas jurídicas, queda meridianamente claro que tales programas son relevantes como objeto de prueba en el proceso penal. Sin embargo, hay que ser cauteloso para no dotarlos de una importancia mayor de la que les corresponde. Así pues, hay que evitar que tales programas se conviertan en una prueba absoluta o autosuficiente, cuya existencia sirva para blindar a la persona jurídica ante las eventuales responsabilidades penales en que pudiera incurrir.

De la mera existencia de un programa de cumplimiento, aun cuando se encuentre avalado por una entidad certificadora de compliance que acredite que cumple con los requerimientos legales (art. $4^{\circ} .4$ Ley 20.393), no se puede deducir que la entidad haya desplegado la diligencia debida o la que razonablemente le sería exigible para prevenir la comisión del delito enjuiciado. Esta valoración, relativa al cumplimiento o incumplimiento de los deberes de supervisión, vigilancia y control, tiene un carácter necesariamente casuístico, tal y como indica el propio CP español con la expresión "atendidas las concretas circunstancias del caso" (art. 31 bis 1 b)) o la Ley 20.393 al exigir que la comisión del delito fuere consecuencia del incumplimiento de los deberes de dirección y supervisión de la entidad (art. $3^{\circ}$ ). Por lo tanto, lo determinante para decidir sobre la responsabilidad penal de las personas jurídicas es el efectivo cumplimiento de los deberes de supervisión y control sobre aquella concreta actividad en la que se ha supuestamente se ha perpetrado la actuación delictiva, sin perjuicio de que la existencia de tales programas preventivos sirva para protocolizar o formalizar tales deberes y, por ende, como indicio de su cumplimiento ${ }^{48}$.

A continuación se indicarán ciertos aspectos que debieran tomarse en consideración para ponderar adecuadamente la relevancia de los programas de cumplimiento penal en la determinación de la responsabilidad de la persona jurídica, sin caer en automatismos que

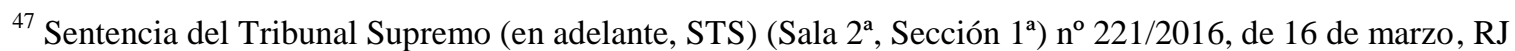
2016/966, fundamento jurídico $5^{\circ}$.

${ }^{48}$ En este sentido, SALVO ILABEL, Nelly, Modelos de imputación penal a personas jurídicas: estudio comparado de los sistemas español y chileno, Tesis doctoral dirigida por CUGAT MAURI, Miriam, Universidad Autónoma de Barcelona: Barcelona, 2014, p. 282, disponible en: http://www.tdx.cat/bitstream/handle/10803/285167/nsi1de1.pdf;jsessionid=0E638570FF686DD7B54A03AB FBBCBD2D.tdx1?sequence=1 [visitado el 12.07.2016], sostiene que "la regulación de los programas de cumplimiento es especialmente útil por cuanto entrega instrucciones claras (...) acerca de cuándo una organización y funcionamiento resultan correcto y cuándo no".
} 
conduzcan a limitar el juicio de reprochabilidad frente a la entidad a una valoración formal del programa de prevención.

- $\quad$ En primer lugar, los programas de cumplimiento, para ser tomados en cuenta por el juzgador, han de ser eficaces, esto es, adecuados para la prevención y detección de los delitos que con mayor probabilidad podrían cometerse en el desarrollo de la actividad de la organización. Además, deben de estar efectivamente implementados en la entidad, lo que implica que sus protocolos y procedimientos de actuación estén siendo aplicados, tanto por sus dirigentes como por el resto de trabajadores y que sus medidas de control se encuentren vigentes. Se descarta así la relevancia de los programas de maquillaje o meramente formales.

- En segundo lugar, la mera existencia de un programa eficaz no puede ser considerada, aisladamente, como circunstancia eximente, en tanto que, habrá que determinar si, en el caso concreto, se omitieron o no los debidos controles. Esto implica, entre otras cosas, acreditar que el programa era eficaz para prevenir los delitos de la especie del que se ha cometido, que el fallo del programa es explicable como un hecho aislado y que el programa ha sido capaz de detectar y reaccionar adecuadamente ante la infracción cometida.

- $\quad$ En tercer lugar, en caso de que estén implicados en el delito, precisamente, los encargados de efectuar tales controles -como los administradores, altos directivos o los propios encargados del programa de cumplimiento- resultará evidente que se ha omitido el control debido o, cuando menos, que los controles implementados eran ineficaces, en tanto que es ilógico sostener que, quien comete un delito, dolosa o imprudentemente, ha desplegado la diligencia debida para evitarlo. Por eso, en mi opinión, cuando los encargados de prevenir o evitar la comisión de delitos están implicados en la actuación delictiva, eximir a la entidad de responsabilidad por tener un programa de cumplimiento eficaz encierra un cierto contrasentido que, tanto la regulación italiana como el CP español, intentan salvar exigiendo, en tal supuesto, la autonomía del órgano encargado de la prevención delictiva respecto del órgano de administración, así como una actuación del presunto autor del delito tendente a eludir o sortear los mecanismos de prevención delictiva implementados en la organización (arts. 6.1 b) y c) D. Lgs. 231 y 31 bis $2.2^{\circ}$ y $3^{\circ} \mathrm{CP}$ ).

A mayor abundamiento, cabe señalar, en este punto, que la implementación de un programa de cumplimiento efectivo no debe ser la única vía para demostrar que ha existido un control debido $^{49}$, lo cual sería inadmisible en un sistema de prueba libre, en el que los medios de prueba no se encuentran legalmente tasados o predeterminados ${ }^{50}$. Por eso, considero que, de la inexistencia de tal modelo no debería deducirse, en todo caso, y de forma automática,

\footnotetext{
${ }^{49}$ En Italia, una vez que se constata la comisión de un delito, en el interés del ente, por un sujeto en posición apical, la única forma de excluir la responsabilidad del ente es haber establecido, antes de la comisión del hecho, un modelo de organización y gestión idóneo para prevenir los delitos de la especie que se ha verificado (art. 6.1.a) D. Lgs. 231).

${ }^{50}$ En este sentido, los sistemas procesales penales español, chileno e italiano condicionan la admisión de las pruebas presentadas por las partes a su utilidad y pertinencia para determinar el objeto del proceso (cfr. arts. 187 y 190 CPP italiano, 659 LECrim y 278 CPP chileno).
} 
NEIRA, Ana María. "La efectividad de los criminal compliance programs como objeto de prueba en el proceso penal".

que el control ejercido sobre los subordinados ha sido insuficiente ${ }^{51}$, siendo procedentes cualesquiera medios de prueba tendentes a determinar que, en el caso concreto, se ejercieron debidamente los deberes de dirección y supervisión. Tales pruebas deben ser admitidas por el juez, salvo que se consideren impertinentes, inútiles o ilícitas, ya que, en otro caso, se vulneraría el derecho de las partes a la prueba (art. 190 CPP italiano, 24.2 Constitución Española y 276 CPP chileno).

En la misma línea, en relación con la regulación chilena de responsabilidad penal de las personas jurídicas, Piña Rochefort afirma, a mi juicio acertadamente, que los requisitos legales no son necesarios ni suficientes para probar que no ha habido un incumplimiento de los deberes de supervisión y dirección, siendo posible que la entidad disponga equivalentes funcionales a los modelos de prevención, esto es, mecanismos de dirección y supervigilancia distintos a los sancionados por la ley, pero que cumplan la misma función ${ }^{52}$.

En definitiva, una vez rechazada la posibilidad de que los programas de cumplimiento sean legalmente irrelevantes, o impertinentes como objeto de prueba, y tras descartar una defensa exacerbada del programa, cabe concluir que el Juez deberá valorar, junto con el resto de pruebas, y atendiendo al principio de libre valoración de las mismas -consagrado en los arts. 192 CPP italiano, 741 LECrim y 297 CPP chileno-, si la persona jurídica actuó de forma diligente en el control de los riesgos delictivos derivados de su actividad, para lo cual la determinación de si existía un programa de cumplimiento eficaz puede resultar muy útil $^{53}$.

El hecho de que el CP especifique, detalladamente, cuál ha de ser el contenido del programa de organización y gestión, señalando que, de no acreditarse todos y cada uno de los extremos referidos en la ley, el programa tendrá una eficacia meramente atenuante, puede resultar contraproducente, en la medida en que tienda a objetivar el juicio sobre la responsabilidad de la entidad, restando libertad al juzgador para realizar un verdadero juicio jurisdiccional que atienda a la materialidad o la reprochabilidad de la conducta empresarial, y no al mero cumplimiento formal de los referidos requerimientos legales.

Igualmente, el hecho de que la regulación italiana señale que, para los delitos cometidos por dependientes, la adopción del modelo de prevención excluye, en todo caso, la inobservancia de las obligaciones de dirección o vigilancia (art. 7.2 D. Lgs. 231) y, por ende, la responsabilidad del ente que depende de esa omisión de control (art. 7.1 D. Lgs. 231), puede restar libertad al juzgador a la hora de determinar si, más allá del cumplimiento formal de los requisitos legales del programa de prevención, la entidad fue diligente en el asunción de sus obligaciones de prevenir y detectar delitos. Por lo tanto, de lege ferenda, parece más adecuado que la presunción legal se establezca en términos menos taxativos,

\footnotetext{
${ }^{51}$ En este sentido, VAN WEEZEL DE LA CRUZ, “Contra la responsabilidad penal”, cit. nota n 21, pp. 138139, tras mostrarse abiertamente contrario a la responsabilidad penal de las personas jurídicas, nos recuerda que la adopción de un modelo de prevención como el que exige la ley no es obligatorio, por lo que, en su ausencia, la acusación tendrá que demostrar el incumplimiento de los deberes de dirección y supervisión, y que la comisión del delito es "consecuencia" de dicho incumplimiento, sin que sea suficiente argumentar que la persona jurídica carecía de modelo preventivo.

${ }^{52}$ PIÑA ROCHEFORT, Modelos de prevención, cit. nota $\mathrm{n}^{\circ} 45, \mathrm{p} .8$.

${ }^{53}$ GIMENO BEVIÁ, Jordi, El proceso penal de las personas jurídicas, Navarra: Aranzadi, 2014, p. 288.
} 
omitiendo la expresión en todo caso, para que quede claro que se trata de una presunción iuris tantum que, por lo tanto, admite prueba en contrario.

\subsection{Los medios probatorios idóneos para introducir los compliance en el proceso penal.}

Una vez establecido que los criminal compliance programs son relevantes como objeto de prueba, se puede afirmar que, consecuentemente, los medios probatorios tendentes a acreditar, su existencia, su efectiva implementación en el seno de la organización y su eficacia preventiva en relación con el delito enjuiciado, resultarán pertinentes y, por lo tanto, en principio, deberán ser admitidos en el proceso por su utilidad para determinar la responsabilidad de la persona jurídica acusada (art. 190 CPP italiano, 24.2 Constitución Española y 276 CPP chileno).

Dicho esto, a continuación, parece adecuado referir aquellos medios probatorios que, $a$ priori, resultan más adecuados para introducir en el debate procesal los programas de cumplimiento normativo y acreditar su existencia, su vigencia y su eficacia.

Así pues, en primer lugar, el programa de cumplimiento, en tanto que deberá encontrarse documentado $^{54}$, deberá ser aportado al proceso como prueba documental. En soporte documental, figurarán, de ordinario, el código ético de la entidad, su mapa de riesgos delictivos, el diseño de su modelo de organización y gestión preordenado a evitar delitos, los protocolos de actuación orientados a prevenir y detectar la comisión de ilícitos, los procedimientos que concreten el proceso de formación de la voluntad de la persona jurídica, así como los procesos de adopción de decisiones y de ejecución de las mismas, la configuración y las funciones del organismo encargado del funcionamiento del programa, el sistema disciplinario, el diseño del canal de denuncias, las labores de comunicación y formación previstas para dar a conocer el modelo entre los distintos agentes que se relacionan con la entidad, así como el procedimiento según el cual se actualizará y adaptará el programa a los cambios en la organización de la entidad o a los que, de otro modo, afecten a la determinación de los riesgos a prevenir.

Sin embargo, a pesar de su innegable utilidad, la aportación documental del programa en cuestión no puede ser considerada suficiente para verificar la efectividad del mismo. Esta insuficiencia se debe a que la eficacia del programa se deriva, no sólo de su configuración genérica o a su diseño, sino también de su efectiva y concreta implementación en la estructura del ente ${ }^{55}$. Por lo tanto, para que se aprecie su eficacia eximente no basta con el establecimiento abstracto de un conjunto de declaraciones programáticas, reflejando el compromiso de la entidad con la cultura de cumplimiento del Derecho, ni siquiera con la previsión de prevenciones y controles concretos, sino que se exige la efectiva implementación o puesta en práctica de tales controles y la adaptación de la actividad del ente, a nivel directivo, organizativo, financiero y operacional, a las reglas o protocolos

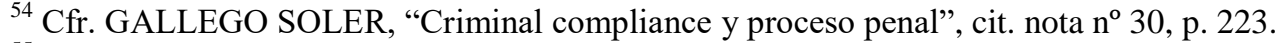

${ }^{55}$ GALLEGO SOLER, "Criminal compliance y proceso penal”, cit. nota $\mathrm{n}^{\circ} 30$, p. 221, afirma que "se trata de valorar tanto la configuración del modelo de prevención de delitos (análisis formal del programa de cumplimiento) como su correcta implementación (análisis material)”.
} 
NEIRA, Ana María. "La efectividad de los criminal compliance programs como objeto de prueba en el proceso penal".

diseñados y preordenados a neutralizar, en la medida de lo jurídicamente exigible, los riesgos delictivos propios de su desempeño.

En este sentido, resulta esencial el archivo y registro documental de la actividad de compliance, esto es, de los documentos generados por la protocolización y formalización de las diversas actividades que desarrolle la entidad, la información recabada a través del canal de denuncias, la documentación de las investigaciones internas desarrolladas a raíz de tales revelaciones y de sus resultados ${ }^{56}$, así como la documentación que genere, en su caso, la aplicación del sistema disciplinario. Igualmente, es preciso documentar la actividad del organismo encargado de la supervisión y vigilancia del sistema, reflejada a través de los informes de auditoría interna, de las revisiones periódicas del modelo o de su adaptación ante cambios en la organización, en la estructura de control o en la actividad del ente, de las actividades que desarrolle la entidad para formar a sus empleados en la cultura de compliance, tales como manuales de formación, cursos etc ${ }^{57}$.

Todas estas actividades implican un trabajo operativo y burocrático que debe ser objeto de archivo documental, siendo el encargado natural del mismo el organismo que tiene encomendada la función de supervisar el modelo de prevención. Así pues, si la entidad cuenta con un programa de cumplimiento eficaz podrá usarlo para ir preconstituyendo pruebas que le podrán servir para quedar exenta de responsabilidad penal si, a pesar de que alguno o algunos de sus miembros hayan delinquido, acredita que empleó toda la diligencia debida para evitarlo.

En principio, ante el requerimiento de la Fiscalía o de forma espontánea la defensa podría entregar esta documentación derivada de la actividad de compliance de forma libre y voluntaria, ya que le serviría para defenderse de la acusación. Ahora bien, si la Fiscalía requiere tal documentación para determinar si se han cumplido o no los deberes de control, y la entidad no responde a tal requerimiento, o si responde, pero entregando información que pareciera ser falsa o incompleta, es posible que se solicite una orden judicial para incautar e inspeccionar tal documentación (arts. 573 LECrim y 217 CPP chileno). A tal fin, será necesario, como norma general, seguir el procedimiento para conducir una entrada y registro en lugar cerrado, el cual, de acuerdo con la regulación española, tendría la consideración de domicilio del ente (art. 554.4 ${ }^{\circ}$ LECrim). Por lo tanto, será necesario, o bien el consentimiento del propietario o, en su defecto, una orden judicial (arts. 205 CPP chileno y 18.2 CE). En este punto, resulta interesante la regulación italiana que permite la

\footnotetext{
${ }^{56}$ Como apunta, NIETO MARTÍN, Adán, “Investigaciones internas, whistleblowing y cooperación: la lucha por la información en el proceso penal”, Diario La Ley, no 8120 (2013), la información que se genera a través del canal de denuncias, así como los resultados de las investigaciones que la entidad decida emprender internamente a raíz de las mismas, podrían reflejar un historial de la vida delictiva de la persona jurídica, cuyo aporte voluntario al proceso podría servirle para atenuar su responsabilidad, o incluso como circunstancia eximente si prueba que, a pesar del delito cometido por alguno de sus empleados, la entidad desplegó el debido control atendidas las concretas circunstancias del caso.

${ }^{57}$ En este sentido, sostiene GÓMEZ-JARA DÍEZ, "La culpabilidad de la persona jurídica”, cit. nota n 26, p. 218, que la denominada "información documentada", prevista en los sistemas de gestión de compliance, puede ser relevante en el ámbito probatorio, al permitir al órgano judicial valorar la vigencia efectiva del modelo.
} 
incautación de la documentación proveniente del imputado, incluso acordada de oficio por el juez, y aun cuando se hallare en poder de un tercero (art. 237 CPP italiano).

Dicho esto, y sin subestimar el valor de la prueba documental, cabe señalar que, posiblemente, las pruebas periciales y las testificales sean medios de prueba igualmente necesarios e idóneos para acreditar la eficacia del modelo de cumplimiento ${ }^{58}$. El motivo radica en que, para valorar la eficacia del programa una foto fija de la situación organizativa de la entidad resulta insuficiente, debiendo valorarse sus medidas preventivas desde una perspectiva dinámica, como dinámica es la realidad en la que intentan influir. Por eso, en contra de quien sostiene que casi toda la prueba que se va a aportar es la documental, en concreto, el programa de compliance ${ }^{59}$, se debe afirmar que las vías probatorias apropiadas para acreditar la existencia y vigencia de los controles diseñados en el programa y, particularmente, su incidencia en la estructura organizativa de la entidad, así como en la presunta comisión del delito perseguido, serán también testificales (de empleados o del compliance officer, así como de clientes o proveedores) o periciales (a través de informes de expertos que se pronuncien sobre la idoneidad y la aptitud de los programas a priori para prevenir delitos ${ }^{60}$. Todos estos medios de prueba se muestran, en abstracto, útiles para introducir los programas de cumplimiento en el proceso.

De hecho, cabe afirmar que lo más habitual será que la eficacia del programa de prevención se acredite procesalmente a través de un experto independiente, que actúe en calidad de perito, como por ejemplo, un certificador o auditor de compliance. Así pues, tales profesionales podrían ser llamados al proceso en calidad de peritos, para evacuar un informe y declarar, en abstracto, sobre la idoneidad y eficacia del programa de cumplimiento para prevenir y detectar delitos de la especie del supuestamente cometido. En este sentido, se afirma que las certificaciones de programas de cumplimiento podrían ser consideradas como una prueba pericial anticipada ${ }^{61}$.

La importancia de la prueba pericial se justifica en la medida en que el programa tiene que reflejar el estado de la técnica en la materia de prevención de riesgos en el sector de que se

\footnotetext{
${ }^{58}$ En esta línea, VELÁZQUEZ VIOQUE, David, "Responsabilidad penal de las empresas. ¿Cómo probar el debido control?", Diario La Ley, no 7794 (2012), sostiene que, una vez efectuado el diagnóstico, resulta necesaria la documentación del conjunto de medidas de prevención y detección de delitos, debiendo aportarse tal protocolo al Juzgado como prueba documental que permite verificar el control debido, sin perjuicio de la aportación como pericial del informe de un experto independiente que corrobore la virtualidad de dicho protocolo y, ante todo, que los controles verdaderamente están implementados y funcionan en el momento presente.

59 VEGAS TORRES, Jaime, "Problemática procesal derivada de la responsabilidad penal de las personas jurídicas", $\quad$ Diario $\quad L a \quad$ Ley, $\mathrm{n}^{\circ} \quad 7626 \quad$ (2011), http://guiasjuridicas.wolterskluwer.es/Content/Documento.aspx?params=H4sIAAAAAAAEAMtMSbF1jTA AAVNDEyNTtbLUouLM_DxbIwNDQwMTQ0OQQGZapUt-ckhlQaptWmJOcSoAjx8fLzUAAAA=WKE [visitado el 21.04.2016].

${ }^{60}$ GASCÓN INCHAUSTI, Fernando, Proceso penal y persona jurídica, Madrid/Barcelona/Buenos Aires/Sao Paulo: Marcial Pons, 2012, p. 147.

${ }^{61}$ NIETO MARTÍN, "Fundamentos y estructura", cit. nota no 16, p. 116.
} 
NEIRA, Ana María. "La efectividad de los criminal compliance programs como objeto de prueba en el proceso penal".

trate $^{62}$. En este sentido, se afirma que la presentación de periciales, realizadas por empresas especializadas, que aseveren la institucionalización efectiva de una cultura de cumplimiento de la legalidad en el momento de cometerse el delito, será, en ciertos casos, la vía idónea para excluir la responsabilidad de la persona jurídica ${ }^{63}$.

Al no existir, en España ni en Italia, ningún procedimiento de verificación ex ante de la eficacia de los programas de cumplimiento, ni estándares jurisprudenciales consolidados sobre qué ha de entenderse por control debido, y siendo normalmente los mecanismos de control de riesgos penales de carácter técnico, y específicos para cada rama de actividad, se obliga al órgano judicial a tener que recurrir a peritos expertos, de cuyo informe, previsiblemente, dependerá, en gran medida, la valoración de la eficacia del programa de cumplimiento y, por lo tanto, la determinación de la responsabilidad del ente ${ }^{64}$.

Surge aquí la cuestión del carácter científico de la prueba, singularmente la suministrada por expertos y peritos, y su compatibilidad con el principio de libre valoración de la prueba. Sobre esta cuestión, afirma Vázquez Sotelo que el Juez debe controlar el grado de aceptación de las conclusiones de los peritos, así como la razonabilidad y fiabilidad de los procedimientos de análisis realizados, ya que, "si al perito toca resolver un problema científico, o una duda técnica, al juez corresponde resolver el problema del proceso, que es siempre un problema humano y de proyección social"65.

Otra cuestión es quién puede actuar como perito para declarar sobre la idoneidad y eficacia del programa de prevención de delitos de la entidad.

Pues bien, según la regulación chilena, serán las partes las que aporten los informes elaborados por peritos de su confianza, que deberán ser admitidos siempre que sus conocimientos se consideren convenientes para valorar la eficacia de los programas de prevención de delitos, en tanto que circunstancia relevante para la causa (art. 314 CPP chileno). Sin perjuicio de ello, se podrá proponer que sean citados a declarar en juicio para interrogarles sobre su imparcialidad, su idoneidad y el rigor de sus conclusiones (art. 318 CPP chileno). En tal caso, parece admisible que el certificador del programa, o la entidad que lo diseñó y lo implementó en la organización enjuiciada, puedan ser llamados como peritos técnicos, tanto por la defensa como por la acusación.

\footnotetext{
${ }^{62}$ En esta línea, COCA VILA, “_Programas de cumplimiento como forma”, cit. nota n 32, p. 63, advierte que, quienes valorarán la eficacia de los programas de cumplimiento, en último término, deberán ser los jueces, si bien tendrán que recurrir, necesariamente, a informes periciales de expertos independientes.

${ }^{63}$ Cfr. GÓMEZ-JARA DÍEZ, “La culpabilidad de la persona jurídica”, cit. nota n 26, p. 218.

${ }^{64}$ Según GALLEGO SOLER, “Criminal compliance y proceso penal”, cit. nota no 30, p. 223, se tratará de una prueba pericial peculiar, puesto que combinará elementos de contenido jurídico-penal y otros de corte más técnico; Por su parte, NIETO MARTÍN, "Fundamentos y estructura", cit. nota no 16, p. 116, indica que, "aunque podría objetarse que la pericia se trata de una prueba sobre una cuestión de derecho, como es el debido control, y que por lo tanto no resulta admisible (...) de acuerdo con el principio iura novit curia, lo cierto es que la efectividad del debido control a través de un programa de cumplimiento es un hecho para cuyo conocimiento son necesarios conocimientos extrajurídicos, provenientes de disciplinas como la auditoría, la criminología, la sociología de la empresa, la dirección empresarial o recursos humanos".

${ }^{65}$ VÁZQUEZ SOTELO, José Luis, Presunción de inocencia del imputado e íntima convicción del tribunal. Estudio sobre la utilización del imputado como fuente de prueba en el proceso penal español, Barcelona: Bosch, 1985, pp. 470-479, esp. 478-479.
} 
En el caso de la legislación italiana habría que distinguir entre los peritos y los consultores técnicos, siendo los primeros nombrados por el juez y los segundos por las partes (arts. 221 y 225 CPP italiano). Para los primeros rigen amplias causas de recusación, por lo que no parece posible que el experto sea llamado como perito cuando ha dado su parecer previamente sobre el objeto del proceso (arts. 223.2 y 36 c) CPP italiano), mientras que se establece como causa de incompatibilidad para actuar como perito el ser llamado a declarar como testigo (art. 222.1.d) CPP italiano). Por lo tanto, si la acusación considera apropiado llamar como testigo a la persona que se encargó de implementar el programa, al encargado de supervisar su funcionamiento o al certificador, esto le inhabilitaría para declarar como perito judicial.

Ahora bien, de acuerdo con la regulación española, si los expertos en compliance llamados al proceso han participado directamente, bien como diseñadores del programa, bien como certificadores del mismo, podrían ser citados en calidad de testigos técnicos o testigosperitos, dado que, habrían percibido ciertos hechos relevantes para el proceso de forma previa o extraprocesal pero, además, contarían con unos especiales conocimientos técnicos sobre la materia objeto del proceso ${ }^{66}$. Por ejemplo, el certificador del programa o, incluso, el compliance officer, podrían ser citados en tal calidad.

En España, la figura del testigo-perito está prevista en el art. 370.4 LECiv, de aplicación supletoria a la LECrim, para aquellos testigos que poseen especiales conocimientos sobre la materia a que se refieren los hechos. Así pues, el encargado de prevención, además de ser interrogado sobre cómo, en el caso concreto, la entidad implementó de forma eficaz el programa, difundiéndolo efectivamente entre sus agentes y empleados, sancionando los incumplimientos del mismo y reaccionando adecuadamente ante las denuncias o sospechas de comisión de delitos, en tanto que experto en la materia de la prevención delictiva y, posiblemente, en los específicos riesgos delictivos propios de la actividad que desarrolle la entidad, también podría emitir un dictamen técnico sobre la idoneidad del modelo para prevenir el tipo de delito cometido o sobre el nivel de riesgo habitualmente asumido en el tipo de actividad de que se trate. Se trataría de un testigo más pero, dada su cualificación, sus aportaciones vendrían matizadas por sus especiales conocimientos técnicos sobre los que también podría ser interrogado. Esta doble condición supone que, al ser interrogado sobre cuestiones técnicas, el perito podrá ser recusado si se entiende que tiene interés directo o indirecto en la causa (art. $468.2^{\circ}$ LECrim).

Igualmente, resultan, en principio, apropiadas para acreditar la eficacia del programa de cumplimiento, las declaraciones testificales de otros miembros del órgano de vigilancia y de los trabajadores del ámbito operativo en el que se produjo el presunto delito, que deberán declarar sobre si, efectivamente, en el desarrollo de la actividad, en la cual, supuestamente, se cometió el delito, las medidas preventivas y los controles descritos en el programa de compliance se encontraban efectivamente implementados y vigentes. Tales sujetos, en caso de tener conocimientos específicos sobre la actividad de prevención de

\footnotetext{
${ }^{66}$ Según BELHADJ BEN GÓMEZ, Celia, "El testigo-perito, proposición y práctica de prueba. Distinción con el perito", Revista Aranzadi Doctrinal, núm. 2 (2014), pp. 1-6, p. 2, es un sujeto que, sin ser parte en el proceso, tiene un conocimiento de los hechos, anterior a la existencia del proceso y, al mismo tiempo, su cualificación profesional le permite agregar a su declaración una valoración técnico-científica.
} 
NEIRA, Ana María. "La efectividad de los criminal compliance programs como objeto de prueba en el proceso penal".

delitos, como previsiblemente ocurrirá con el encargado de prevención, o sobre la específica actividad en la que se cometió el delito -como podría ocurrir, por ejemplo, con el director de finanzas, el jefe de contabilidad, el encargado de la gestión de residuos o el controller de la sección de calidad, según el tipo de delito que supuestamente se haya cometido-, también podrían ser llamados a declarar, en su caso, en calidad de testigosperitos.

El hecho de que el sujeto sea citado como perito o como testigo-perito dependerá de si su relación con los hechos es previa e independiente del proceso o no ${ }^{67}$, lo cual, seguramente, vendrá, al menos en parte, determinado por su mayor o menor integración en el organigrama de la entidad, así como por la intervención personal que, eventualmente, haya tenido en el diseño, implementación, certificación o supervisión del programa de cumplimiento cuya eficacia pretende valorarse.

En definitiva, determinar que no ha concurrido, en la perpetración del hecho delictivo, una omisión relevante del control debido, es una cuestión jurídica que corresponde valorar al órgano judicial. Ahora bien, tal valoración se podría fundamentar en la existencia e idoneidad de un modelo de organización empresarial dirigido a prevenir los delitos de la especie del que se ha verificado, en tanto que, de la acreditación de la existencia de tal modelo en el momento de cometerse el delito, podría inferirse que, en el caso concreto, la entidad fue diligente en el cumplimiento de sus obligaciones de control.

No es difícil adivinar que la valoración de tal extremo, cuál es, el cumplimiento de los deberes de vigilancia, control y prevención, deberá realizarse de forma casuística por el juzgador, Pero, para ello, se precisará, normalmente, el testimonio de los trabajadores de la entidad a cuya actividad afecte la implementación del programa, el testimonio de los directivos encargados de supervisar y aplicar de forma efectiva las medidas de control, así como la opinión de expertos o peritos que verifiquen la eficacia ex ante del programa, para lo cual han de conocer los riesgos específicos del sector o de la actividad en cuestión, así como el umbral de riesgo cotidianamente asumible o aceptable en el tipo de industria o negocio de que se trate, cuestiones que, por otra parte, no son en absoluto inmutables en el tiempo.

En resumen, la prueba documental es útil porque sirve para valorar la adecuación de la actividad de identificación y valoración de los riesgos y la corrección del diseño del programa de cumplimiento. Sin embargo, tal medio probatorio, siendo necesario, no es autosuficiente, sino que necesita ser, previsiblemente, complementado por la prueba pericial, que sirve para valorar la eficacia del programa, tanto en abstracto, para los riesgos delictivos detectados, como en concreto, para el tamaño, la actividad y la estructura organizativa del ente $\mathrm{y}$, en todo caso, por la prueba testifical, que acredite la efectiva

\footnotetext{
${ }^{67}$ BELHADJ BEN GÓMEZ, "El testigo-perito, proposición y práctica", cit. nota $n^{\circ} 66, p .3$, señala que el perito no tiene conocimiento de los hechos discutidos en juicio antes de realizar el informe pericial, mientras que el testigo-perito posee un conocimiento directo de los mismos.
} 
implementación del programa en la organización y la adaptación de su estructura y su funcionamiento al modelo definido en el programa diseñado.

\subsection{La certificación de los programas de cumplimiento y su valor relativo para acreditar su eficacia.}

La regulación chilena contempla la posibilidad de que la eficacia de los compliance sea auditada o certificada ex ante por organismos especializados, independientes de la entidad (art. $4^{\circ} .4$ ) b) Ley 20.393). Este aval de una entidad externa, que acredite la eficacia y la idoneidad del modelo de prevención de delitos implementado por la organización, podría suponer un plus de seguridad jurídica para las corporaciones potencialmente infractoras. Tales certificaciones vendrían a homogeneizar los criterios de valoración de la eficacia de los programas de cumplimiento, lo que podría servir de protección ante la previsible disparidad de los órganos judiciales, encargados, en última instancia, de llevar a cabo tal evaluación de los programas, como parte del juicio jurisdiccional sobre la responsabilidad de la persona jurídica.

Sin embargo, lo cierto es que, al menos hasta el momento, el valor de tales certificaciones en un eventual proceso penal resulta incierto. Esto se explica, en primer lugar, porque la certificación está en manos de empresas privadas, algunas de las cuales comparten intereses comerciales de diversa índole con las entidades certificadas. En segundo lugar, por la inexistencia de un procedimiento de certificación estandarizado, que obliga al juzgador a valorar casuísticamente como se ha realizado la certificación y el seguimiento de la entidad. $\mathrm{Y}$, en tercer lugar, por la escasa o nula jurisprudencia al respecto, que impide conocer la posición de la fiscalía y la judicatura sobre el valor de las certificaciones.

Por otra parte, tal externalización y tecnificación en la valoración de un elemento clave para apreciar la responsabilidad penal de las personas jurídicas puede implicar riesgos para la independencia e imparcialidad judicial a la hora de valorar libremente las pruebas que las partes aportan al proceso. En este sentido, nuevamente, "es necesario estar precavido para no caer en los "excesos del cientifismo" de la prueba" 68 .

Aunque a la empresa certificadora, especialista en gestión de riesgos o en la implementación de programas de cumplimiento, le corresponda evaluar los riesgos delictivos de la entidad y analizar la estructura de la organización para cerciorarse de que el programa es eficaz para prevenir y detectar delitos, al Juez le corresponderá determinar si, en el caso concreto, el delito pudo cometerse como consecuencia de un incumplimiento grave de los deberes de dirección, supervisión o control de la entidad. De tal juicio jurisdiccional, basado en todas las pruebas útiles y pertinentes practicadas a tal fin en la vista oral, se derivará la condena o absolución de la persona jurídica, independientemente de que esta cuente o no con un programa certificado. Por eso, lo esencial de la tarea del certificador, más allá de emitir inicialmente un certificado, será realizar una labor de seguimiento de las políticas de cumplimiento penal de la entidad e ir, de este modo,

\footnotetext{
${ }^{68}$ VÁZQUEZ SOTELO, Presunción de inocencia del imputado, cit. nota no 65 , pp. 477-478.
} 
NEIRA, Ana María. "La efectividad de los criminal compliance programs como objeto de prueba en el proceso penal".

preconstituyendo y recopilando pruebas válidas para un eventual proceso penal ${ }^{69}$.

Con la actividad de certificación o verificación de la eficacia de los programas de cumplimiento surge la figura del auditor de compliance. Estas funciones, según la regulación chilena, pueden ser desarrolladas por empresas de auditoría externa, por sociedades clasificadoras de riesgo o por otras entidades registradas ante la Superintendencia de Valores y Seguros (en adelante, SVS) ${ }^{70}$.

La colaboración público-privada en la certificación de los modelos de prevención de delitos presenta el riesgo de que existan conflictos de interés entre las entidades certificadoras y las empresas que pretenden certificar sus programas. Por eso, resulta muy adecuada, aunque quizás excesivamente limitada, la incompatibilidad señalada en una norma dictada por la propia SVS, en la que se prohíbe a las sociedades certificadoras emitir certificados en favor de sociedades a las que previamente han asesorado en relación con el diseño e implementación del modelo de prevención, así como en favor de otras relacionadas o del mismo grupo que aquellas o de las que integran un grupo empresarial con la propia entidad certificadora $^{71}$.

En mi opinión, la incompatibilidad debería resultar igualmente extensible a otras relaciones comerciales que la certificadora pudiera establecer con la entidad certificada, por ejemplo en calidad de asesora legal, consultora o auditora contable, entre otras. Ahora bien, al referirse la ley a esas otras entidades que podrían desarrollar labores de certificación abre la puerta a empresas de consultoría o asesoría legal o empresarial, así como también a empresas especializadas en la actividad de certificación. Desde luego, para evitar conflictos de intereses, lo ideal parece ser que la empresa certificadora se limite a realizar las funciones de certificación, sin ofrecer, adicionalmente, otros servicios.

La independencia y la neutralidad del certificador es clave para determinar la calidad y la fiabilidad de estos servicios ${ }^{72}$. Acudiendo a la terminología propia de la auditoría contable, se podría hablar del escepticismo profesional, entendido como una actitud que incluye una mentalidad inquisitiva, una especial atención a las circunstancias que puedan ser indicativas de posibles incorrecciones debidas a errores o fraudes, y una valoración crítica de la evidencia de auditoría ${ }^{73}$.

\footnotetext{
${ }^{69}$ Es por eso que NIETO MARTÍN, "Fundamentos y estructura", cit. nota ${ }^{\circ} 16$, pp. 113 y 116, afirma que "La certificación de los programas de cumplimiento puede resultar de utilidad como instrumento de defensa penal de la entidad", ya que puede servir como prueba documental y como "prueba pericial anticipada".

${ }^{70}$ Actualmente, existen más de una veintena de entidades habilitadas como certificadoras de los modelos de prevención de delitos, cuyos servicios pueden ser solicitados a través de la web de la SVS, accesible en: http://www.svs.cl/institucional/servicios/certificados/emision.php [visitado el 21.04.2016]

${ }^{71}$ Sección III, norma 302, de 25 de enero de 2011, emitida por la SVS que establece normas que deben cumplir las empresas de auditoría externa, sociedades clasificadoras de riesgo y demás entidades para cumplir la labor de certificación de modelos de prevención de delitos a que se refiere la Ley 20.393.

${ }^{72}$ En este sentido, NIETO MARTÍN, "Fundamento y estructura", cit. nota $\mathrm{n}^{\mathrm{o}} 10$, p. 117, afirma que un aspecto central en la regulación de la certificación es asegurar la independencia y profesionalidad de las entidades certificadoras.

${ }^{73}$ Definido en la Norma Internacional de Auditoría 200.13(1) (adaptada para su aplicación en España mediante Resolución del Instituto de Contabilidad y Auditoría de Cuentas, de 15 de octubre de 2013) disponible en: http://www.icac.meh.es/nias/nia\%20200\%20p\%20def.pdf [visitado el 12.07.2016]
} 
En cuanto al proceso de certificación y a la determinación de los elementos que resultan auditables, la Ley 20.393 señala que el certificado señalará que el modelo contempla los requisitos establecidos por la ley, en relación a la situación, tamaño, giro, nivel de ingresos y complejidad de la persona jurídica (art. 4.4. b)). Sin embargo, esta foto fija a la que se refiere la ley, no parece suficiente para acreditar la eficacia de un modelo cuya efectividad ha de ser valorada desde una perspectiva esencialmente dinámica y prolongada en el tiempo.

En el proceso de certificación pueden distinguirse, siguiendo a Piña Rochefort ${ }^{74}$, dos dimensiones, el juicio abstracto del modelo, que se limita a acreditar que la entidad cumple con los requerimientos de mínimos que fija la ley, y el juicio concreto, que evalúa si el modelo se encuentra efectivamente implementado en la estructura organizativa. Esta segunda dimensión es sin duda la más compleja, entre otras cosas porque requiere de una actualización permanente, que implica, entre otras cosas, que las certificaciones nacen con fecha de caducidad.

Para que la certificación acredite la eficacia del modelo es preciso establecer un plan de seguimiento de la certificadora en relación con la actividad de la entidad certificada, tanto a nivel organizativo, como operativo y financiero. De esta forma, a través de la interactuación continuada entre la entidad certificada y la certificadora, se establece entre ellas una relación dinámica y prolongada en el tiempo, que permite a la certificadora, por una parte, ir recopilando evidencias sobre la actuaciones implementadas por su cliente para cumplir la ley $\mathrm{y}$, por otro, detectar fallas o brechas en el programa y proponer las necesarias actualizaciones y adaptaciones del modelo. Los test y controles desarrollados por la certificadora deberán de reflejarse en su informe pericial en forma de relación circunstanciada de operaciones tendientes a determinar la idoneidad y la eficacia del programa de prevención (art. 315 b) CPP chileno).

En Italia, los programas son diseñados de conformidad con los códigos de conducta confeccionados por asociaciones representativas del sector al que pertenece la entidad en cuestión. Tales asociaciones representativas comunican el código al Ministerio de Justicia para que este, a través del Director General de la Justicia Penal, lo examine y valore su adecuación a los requerimientos legales contenidos en el D. Lgs. 231.

El Director General de la Justicia Penal, previa consulta con los otros Ministerios competentes, y pudiendo valerse del asesoramiento de expertos en administración, dirección y organización de empresas, comunicará, en su caso, a la asociación representativa del sector, las observaciones sobre la idoneidad del código para que, en su caso, esta incorpore los cambios pertinentes o, en otro caso, si no considera necesario incorporar cambios, convalide el código, que servirá de base para la elaboración de los programas de las personas jurídicas que operan en el sector ${ }^{75}$.

\footnotetext{
${ }^{74}$ PIÑA ROCHEFORT, Modelos de prevención, cit. nota $\mathrm{n}^{\circ}$ 45, pp. 90-93.

${ }^{75}$ Este procedimiento aparece regulado en los arts. 5, 6 y 7 D. 26 de junio de 2003, no 201, Regolamento recante disposizioni regolamentari relative al procedimento di accertamento dell'illecito amministrativo delle persone giuridiche, delle società e delle associazioni anche prive di personalità giuridica, ai sensi dell'articolo 85 del decreto legislativo 8 giugno 2001, n. 231.
} 
NEIRA, Ana María. "La efectividad de los criminal compliance programs como objeto de prueba en el proceso penal".

Este sistema presenta como ventaja que, en el proceso de diseño de los programas de cumplimiento, hay autoridades públicas involucradas que, valiéndose del saber de expertos en la materia, señalan, sectorialmente, como ha de ser el modelo de prevención de delitos para ser eficaz e idóneo en la prevención de los riesgos propios del sector de que se trate. Ahora bien, tal y como está diseñado el modelo italiano, ajustarse a los requerimientos del código base, sólo asegura que la formulación del programa es correcta, pero no garantiza nada en relación con su correcta implementación y actualización.

En España, no se ha regulado legalmente la posibilidad de que los programas de cumplimiento sean auditados. Ahora bien, resulta digna de mención, en este sentido, la labor de la Asociación Española de Certificación y Normalización (en adelante, AENOR), que es una entidad privada y sin ánimo de lucro, que se rige por los estándares fijados por la norma UNE-ISO 19600:2015 de "Sistemas de Gestión de Compliance".

AENOR ha publicado un informe titulado "Sistemas de gestión de riesgos para la prevención de delitos en las organizaciones" en el que indica que el sistema de prevención de delitos consiste en:

"un modelo que incluye requisitos auditables para prevenir la comisión de actos constitutivos de delitos que puedan cometerse bajo la cobertura de la persona jurídica y que lleven aparejada responsabilidad penal para la misma, así como reparar y disminuir los efectos de los delitos cometidos y con ello ayudar a reducir la responsabilidad penal de las empresas y organizaciones y de sus administradores y responsables legales, a través del uso de la mejora continua. Este sistema incluye la comprobación por parte de un equipo experto de auditores del cumplimiento de los requisitos, de la implantación y mantenimiento efectivo del sistema" ${ }^{76}$.

En cualquier caso, las certificaciones "no pueden ser por sí mismas una constatación de que se ha adoptado un modelo de prevención idóneo y eficaz"77, sino que será necesario comprobar si, atendidas las concretas circunstancias del caso, el programa en abstracto y su efectiva implementación en la entidad resultaban medidas idóneas para mantener los riesgos penales en niveles jurídicos aceptables. Y esto sólo vendrá acreditado por la entidad certificadora cuando haya habido un seguimiento real y efectivo de las actividades de la entidad certificada.

En suma, cabe afirmar que el plan de prevención se diseña desde una perspectiva ex ante, mientras que, evidentemente, la responsabilidad se determinará desde una perspectiva ex post $^{78}$. De tal dicotomía se deriva una inevitable dosis de inseguridad en cuanto a la eficacia del programa para prevenir aquellos riesgos que, finalmente, se han materializado en un resultado lesivo $\mathrm{y}$, por ende, en cuanto a la efectividad del modelo para eximir de responsabilidad penal a la entidad. Para reducir esa incertidumbre la persona jurídica sólo

\footnotetext{
76 Así lo señala Salvador Román, Gerente de responsabilidad social de AENOR, en el informe sobre trasparencia disponible

en:

http://webantigua.transparencia.org.es/seminario_prevencion_corrc._sector_privado/ponencias/salvador_roma n.pdf [visitado el 12.07.2016].

${ }^{77}$ GALLEGO SOLER, “Criminal compliance y proceso penal”, cit. nota $\mathrm{n}^{\mathrm{o}} 30$, p. 225

${ }^{78}$ GOÑI SEIN, "Programas de cumplimiento empresarial”, cit. nota $n^{\circ} 3$, pp. 374-375.
} 


\section{Polít. crim. Vol. 11, № 22 (Diciembre 2016), Art. 5, pp. 467-520. \\ [http://www.politicacriminal.cl/Vol_11/n_22/Vol11N22A5.pdf]}

puede ir archivando y preconstituyendo pruebas que, en un eventual proceso penal, sirvan para acreditar que los instrumentos de prevención y detección de delitos del programa se encontraban vigentes y funcionaban adecuadamente en el momento en que se cometió el delito.

En la misma línea, la FGE señala que:

"las certificaciones sobre la idoneidad del modelo expedidas por empresas o asociaciones evaluadoras y certificadoras de cumplimiento de obligaciones, mediante las que se manifiesta que un modelo cumple las condiciones y requisitos legales, podrán apreciarse como un elemento adicional más de la adecuación del modelo pero en modo alguno acreditan su eficacia, ni sustituyen la valoración que de manera exclusiva compete al órgano judicial" ${ }^{, 79}$.

Por su parte, el MP de Chile también señala que "la empresa no se exime de responsabilidad por el mero hecho de contar con esa certificación", ya que es posible que el modelo, aun cumpliendo con la normativa, no se corresponda con la verdadera política de negocios de la organización, lo que pondría de manifiesto la falta de aplicación efectiva del $\operatorname{mismo}^{80}$.

En definitiva, las certificaciones no pueden entenderse como "prueba reina" y autosuficiente para acreditar la eficacia de los programas de cumplimiento y su efectiva implementación en la organización, ni tampoco pueden servir para hurtar al Juez la facultad de valorar libremente si, en el caso concreto, el delito, presuntamente cometido, puede, razonablemente, atribuirse, o no, a los excesivos riesgos en que incurrió la entidad con su actividad o a la falta de medidas de vigilancia y control para neutralizar o reducir tales riesgos $^{81}$. En otras palabras, la asunción excesiva de riesgos por la persona jurídica, como núcleo del injusto que se imputa a la organización, debe ser objeto de un verdadero juicio jurisdiccional.

Algunos autores vinculan la existencia de una certificación con la carga de la prueba sobre la eficacia de los mecanismos de prevención de la entidad, entendiendo que las empresas que hayan certificado su modelo contarán con una presunción de cumplimiento que deberá ser desvirtuada por el Ministerio Público, mientras que aquellas que no lo hayan certificado deberán probar que, a pesar de la comisión del delito, su modelo de prevención es idóneo para cumplir con su función ${ }^{82}$. En la misma línea, Nieto Martín señala que los estándares

\footnotetext{
${ }^{79}$ FGE, Circular 1/2016, p. 52.

${ }^{80}$ MP de Chile, Oficio FN n ${ }^{\circ} 440 / 2010$, p. 10.

${ }^{81}$ En esta línea, NIETO MARTÍN, "Fundamentos y estructura", cit. nota $\mathrm{n}^{\circ} 16$, p. 117, advierte que la certificación no va a tener un valor probatorio absoluto, pues en el derecho penal no son admisibles las pruebas regladas y rige el principio de libre valoración de la prueba. Sin embargo, el autor augura que "su valor se incrementará a medida que se consoliden como criterios técnicos únicos, eliminando la posibilidad de contraste".

${ }^{82}$ En este sentido, HERNÁNDEZ BASUALTO, Héctor, "La introducción de la responsabilidad penal de las personas jurídicas en Chile", Polít. Crim., vol. 5, no 9 (2010), pp. 207-236, p. 227, en: http://www.scielo.cl/scielo.php?script=sci_arttext\&pid=S0718-33992010000100005 [visitado el 21.04.2016] sostiene que "en caso de no contar con certificado, es la empresa la que debe demostrar que ha cumplido con
} 
NEIRA, Ana María. "La efectividad de los criminal compliance programs como objeto de prueba en el proceso penal".

procedentes de las investigadoras privadas podrían servir para establecer una presunción iuris tantum favorable a la eficacia del modelo si bien, posteriormente, muestra algunos reparos sobre la credibilidad y la independencia de las entidades certificadoras ${ }^{83}$.

En mi opinión, la anterior argumentación no es del todo correcta, en tanto que, independientemente de que el programa de cumplimiento se encuentre certificado o no, o incluso de que exista o no, la acusación será la encargada de probar que el delito se cometió como consecuencia de un ejercicio insuficiente de los deberes de supervisión y control de la entidad o por la asunción excesiva de riesgos por parte de la organización. Probado lo anterior, la persona jurídica, para quedar exenta de responsabilidad, deberá acreditar que contaba con mecanismos idóneos para prevenir y detectar delitos, los cuales pueden haber adoptado la forma de un modelo de prevención delictiva típico y auditable o no, y pueden haber sido objeto de certificación o no.

De hecho, considero que el automatismo que propone que la certificación funcione como una presunción de eficacia del modelo, situando en una situación probatoria privilegiada a la entidad cuyo modelo ha sido certificado resulta peligroso. En primer lugar, porque no todas las empresas pueden permitirse desembolsar el coste de certificar sus programas, con lo que tal interpretación puede ser discriminatoria para aquellas entidades con menos recursos. Y, en segundo lugar, porque no existe un proceso de certificación estandarizado y consecuentemente la certificación en sí misma no acredita nada. Lo que sirve, al fin y al cabo, para acreditar la eficacia del programa son las garantías que ofrece el proceso de certificación, esto es, los controles implementados por la certificadora sobre la entidad certificada y las pruebas que a través de la relación de seguimiento entre ambas empresas se van produciendo y recopilando. Y eso es, precisamente, lo que debe acceder al proceso en soporte documental y, en su caso, citando al certificador como perito en la vista oral para interrogarle sobre su imparcialidad, su idoneidad y el rigor técnico de sus conclusiones (art. 318 CPP chileno).

En definitiva, la existencia de una certificación, otorgada por una entidad externa e independiente, resultará relevante, si bien no determinante, de la eficacia del sistema de prevención delictiva de la entidad. Ahora bien, previsiblemente, será preciso que la entidad certificadora sea llamada al proceso, ya como testigo, ya como perito, para explicar en qué ha consistido y qué garantías ofrece el procedimiento de certificación desarrollado.

\subsection{La carga de la prueba sobre la eficacia de los programa de cumplimiento normativo.}

3.4.1. La naturaleza dogmática de los programas de cumplimiento como fuente de incertidumbre sobre las reglas de la carga de la prueba.

La dificultad de encajar los programas de cumplimiento normativo en alguna de las categorías de la teoría jurídica del delito se traduce en opiniones divergentes en lo que se refiere a la carga de la prueba sobre la existencia y eficacia de tales programas. En este

sus deberes de dirección y supervisión”; Cfr. PIÑA ROCHEFORT, Modelos de prevención, cit. nota n 45, p. 90 .

${ }^{83}$ NIETO MARTÍN, "Problemas fundamentales del cumplimiento”, cit. nota no 2, pp. 28-29, 42-43. 
sentido, quienes configuran el incumplimiento de los deberes de prevención como núcleo del injusto imputable a las personas jurídicas o como fundamento de su culpabilidad entienden que es la acusación la que ha de acreditar tal extremo, mientras que aquellos que entienden la existencia de tales programas de prevención y su efectiva implementación en la organización como una circunstancia eximente hacen recaer tal carga en la propia organización acusada $^{84}$.

La FGE sostiene que la construcción de los programas de cumplimiento en el sistema de responsabilidad de las personas jurídicas del $\mathrm{CP}$ español remite inequívocamente a la punibilidad y a sus causas de exclusión, de tal forma que, concurrentes en el momento en el que la persona física comete el delito, los modelos de organización operarán a modo de excusa absolutoria, como una causa de exclusión personal de la punibilidad ${ }^{85}$. Consecuentemente, correspondería a la persona jurídica acreditar que sus modelos de organización y gestión cumplen con las condiciones y requisitos legales y que son eficaces en su función de prevención delictiva.

En la misma línea, el voto particular a la STS de 29 de febrero de $2016^{86}$ niega que la ausencia de una cultura de control sea un elemento objetivo del tipo que deba ser, en todo caso, probado por la acusación. Así pues, la opinión minoritaria recogida en tal resolución afirma que, tratándose de una circunstancia eximente que excluye la culpabilidad, "corresponde a la persona jurídica alegar su concurrencia, y aportar una base racional para que pueda ser constatada la disposición de estos instrumentos", sin que sea exigible imponer a la acusación la acreditación del hecho negativo de su no concurrencia ya que esto supondría, según se argumenta en la resolución, configurar un modelo probatorio excepcional y privilegiado para las personas jurídicas, que carecería de justificación.

Otro argumento que conduce a la misma conclusión es el empleado por la FGE refiriéndose a la cuestión de la facilitación probatoria, acercándose a una suerte de teoría dinámica de la carga de la prueba, al situar tal carga en aquel sujeto que, en principio, tiene más facilidades para aportar las evidencias requeridas. La carga dinámica de la prueba es, en definitiva, "una regla que permite al juez en el caso concreto determinar cuál de las partes debe correr con las consecuencias de la falta de prueba de determinado hecho, en virtud a que a ésta le resulta más fácil suministrarla" ${ }^{\prime 7}$. En este sentido, la FGE señala que es la propia empresa

\footnotetext{
${ }^{84}$ En contra de que la carga de la prueba dependa de la configuración dogmática de tales programas se pronuncia la sentencia del STS (Sala 2a, Sección 1 ${ }^{a}$ ) n ${ }^{\mathrm{o}}$ 221/2016, de 16 de marzo, RJ 2016/966, señalando que "ya se califiquen esas causas obstativas de la responsabilidad penal de las personas jurídicas como subsistema de circunstancias eximentes, ya se predique de ellas la condición de excusas absolutorias, de causas de exclusión de la culpabilidad o, como ha llegado a sostenerse, elementos negativos del tipo, la controversia sobre la etiqueta dogmática no puede condicionar el estatuto procesal de las personas colectivas como sujeto singular y diferenciado de la imputación penal. En efecto, de hacerlo así se estaría olvidando que, sea cual fuere el criterio doctrinal mediante el que pretenda explicarse la responsabilidad de los entes colectivos, ésta no puede afirmarse a partir de la simple acreditación del hecho delictivo atribuido a la persona física" (fundamento jurídico $5^{\circ}$ ).

${ }^{85}$ FGE, Circular 1/2016, p. 56.

${ }^{86}$ Voto particular a la STS (Sala 2a, Sección $1^{\text {a)}}$ ) no 154/2016, de 29 de febrero, RJ 2016 600 , fundamento jurídico $3^{\circ}$.

${ }^{87}$ BERMÚDEZ MUÑOZ, Martín, "El futuro de la carga de la prueba en materia de responsabilidad", Revista Temas Jurídicos, Colombia: Colegio Mayor de Nuestra Señora del Rosario, no 11, (1997) pp. 16-38, p. 16;
} 
NEIRA, Ana María. "La efectividad de los criminal compliance programs como objeto de prueba en el proceso penal".

la que cuenta con los recursos y con mayores posibilidades de acreditar que, pese a la comisión del delito, su programa era eficaz y cumplía los estándares exigidos legalmente, al encontrarse en las mejores condiciones de proporcionar de manera única e insustituible los datos que atañen a su organización ${ }^{88}$.

Por su parte, la jurisprudencia italiana, aun reconociendo que el incumplimiento de los deberes de dirección y supervisión es el núcleo de la culpabilidad de la empresa, no aprecia que exista una ilegítima inversión de la carga de la prueba cuando, por disposición legal, tal incumplimiento se presume, con carácter iuris tantum, de la actuación de delictiva de un sujeto apical, exigiendo, en tal caso, que la organización acredite ciertos extremos para poder quedar exenta de responsabilidad ${ }^{89}$.

En sentido contrario, el Tribunal Supremo español (en adelante TS), en una reciente sentencia, señaló que:

"en la medida en que el defecto estructural en los modelos de gestión, vigilancia y
supervisión constituye el fundamento de la responsabilidad del delito corporativo, la
vigencia del derecho a la presunción de inocencia impone que el Fiscal no se considere
exento de la necesidad de acreditar la concurrencia de un incumplimiento grave de los
deberes de supervisión" 90 . En la misma línea, el mismo órgano judicial, en una
resolución anterior, dispuso que "si la acusación se ha de ver lógicamente obligada,
para sentar los requisitos fácticos necesarios en orden a calificar a la persona jurídica
como responsable, a afirmar la inexistencia de tales controles, no tendría sentido
dispensarla de la acreditación de semejante extremo esencial para la prosperidad de su
pretensión"91.

Así mismo, el MP de Chile, en su instrucción 440, señala que todos los presupuestos de imputación de responsabilidad penal de las personas jurídicas, entre los que se encuentra el incumplimiento de los deberes de dirección y supervisión, deben ser acreditados por la acusación, sobre la que recae la carga probatoria ${ }^{92}$. Este presupuesto requiere, por lo tanto,

Sobre esta teoría, véase también PINOCHET CANTWELL, Francisco José, "Cargas dinámicas de la prueba: El agravamiento en Chile" en: GÓMEZ COLOMER, Juan Luis; BARONA VILAR, Silvia; CALDERÓN CUADRADO, María Pía (Coords.) El Derecho procesal español del siglo XX a golpe de tango. Juan Montero Aroca. Liber Amicorum, en homenaje y para celebrar su LXX cumpleaños, Valencia: Tirant lo Blanch, 2012, pp. 729-760.

${ }^{88}$ Circular 1/2016, p. 57.

${ }^{89}$ Sentencia de la Corte de Casación Penal italiana, Sección 6, de 17 de noviembre de 2009, n 36083; Sentencia de la Corte de Casación Penal italiana, Sección 6, de 16 de julio de 2010, nº 27735.

${ }^{90}$ STS (Sala 2a , Sección 1 ${ }^{\text {a }}$ ) n $221 / 2016$, de 16 de marzo, RJ 2016/966, fundamento jurídico 5º En la misma línea, el Consejo de Estado de España, en un Dictamen aprobado el 27 de junio de 2013 (nº expte. 358/2013), señala que la acreditación de la inexistencia del programa de compliance o su inaplicación debería recaer sobre las partes acusadoras.

${ }^{91}$ STS (Sala 2a, Sección 1 ${ }^{\text {a }}$ ) no 154/2016, de 29 de febrero de 2016, RJ 2016\600, fundamento jurídico $8^{\text {o }}$. En esta misma resolución, sostiene el TS que "la determinación del actuar de la persona jurídica, relevante a efectos de la afirmación de su responsabilidad penal (...) ha de establecerse a partir del análisis acerca de si el delito cometido por la persona física en el seno de aquella ha sido posible, o facilitado, por la ausencia de una cultura de respeto al Derecho, como fuente de inspiración de la actuación de su estructura organizativa e independiente de la de cada una de las personas físicas que la integran";

${ }^{92}$ MP de Chile, Oficio FN nº 440/2010, p. 5. 
una actividad de investigación y prueba, de la cual no se exime a la Fiscalía, ni siquiera cuando la entidad no cuenta con un modelo de prevención de delitos como el propuesto por la ley $^{93}$.

En cuanto al encuadramiento dogmático de los programas de prevención de delitos, en la doctrina, se pueden encontrar, así mismo, opiniones encontradas. Por ejemplo, Gómez-Jara Díez, en la línea de la opinión mayoritaria del TS, sostiene que la tipicidad objetiva del injusto típico de la persona jurídica consiste en la organización de la entidad de forma que se superen los niveles de riesgo permitido y en la materialización de tal riesgo en un resultado lesivo, mientras que su culpabilidad se fundamentaría en la cultura empresarial de incumplimiento de la legalidad ${ }^{94}$. Igualmente, Piña Rochefort entiende que la existencia de un modelo de prevención de delitos eficaz implica la atipicidad de la conducta ${ }^{95}$. De forma similar, Collado González viene a situar la inexistencia de estos programas en la tipicidad, al entender que, si hay un programa eficaz y, a pesar de ello se comete el delito, no podrá apreciarse imprudencia en la actuación del ente a la hora de organizarse ${ }^{96}$.

Otros autores optan por asimilar el defecto organizativo o la falta de control debido a la culpabilidad empresarial, constituyendo aquel el equivalente funcional de este elemento de la teoría jurídica del delito ${ }^{97}$. Por su parte, Nieto Martín sostiene que la función del defecto de organización en la offense, esto es, en la prohibición cuyo incumplimiento se imputa a la persona jurídica, es similar a la de una condición objetiva de punibilidad, como la que cumple en el delito de quiebra alemán la declaración de insolvencia ${ }^{98}$. En cualquier caso, de tales opiniones doctrinales se deriva que es la acusación la que debe probar la inexistencia o ineficacia del modelo de prevención.

\footnotetext{
${ }^{93}$ MP de Chile, Oficio FN no 440/2010, p. 7.

${ }^{94}$ GÓMEZ-JARA DÍEZ, "Fundamentos de la responsabilidad penal” cit. nota no 28, pp. 105-107.

${ }^{95}$ PIÑA ROCHEFORT, Modelos de prevención, cit. nota $\mathrm{n}^{\circ} 45, \mathrm{p} .7$.

${ }^{96}$ COLLADO GONZÁLEZ, Rafael, Empresas criminales. Un análisis de los modelos legales de responsabilidad penal de las personas jurídicas implementados en Chile y en España, Thomson Reuters: Santiago de Chile, 2013, pp. 81-82.

${ }^{97}$ En este sentido, el concepto de culpabilidad por defecto de organización (Organisationverschulden) es atribuido, generalmente a TIEDEMANN, Klaus, "Die "Bebüssung von Unternehmen nach dem 2" Gesetz zur Bekämpfung der Wirtschaftskriminalität”, Neue Juristische Wochenschrift, núm. 41 (1988), pp. 1172 y ss.; Los defensores de esta concepción de la culpabilidad empresarial son muy numerosos. Así pues, en la doctrina española, es defendida, entre otros, por BACIGALUPO ZAPATER, Enrique, "Responsabilidad penal y administrativa en las personas jurídicas y programas de "compliance" (A propósito del Proyecto de reformas del Código Penal de 2009)”, Diario La Ley, núm. 7742, 9 de julio de 2010; En la doctrina italiana es seguida por CADOPPI, Alberto; GARUTI, Giulio; VENEZIANI, Paolo, Enti e responsabilità da reato, Turín: Utet Giuridica, 2010, p. 328; Y en la chilena por ARTAZA VARELA, Osvaldo, "Sistemas de prevención de delitos o programas de cumplimiento. Breve descripción de las reglas técnicas de gestión del riesgo empresarial y su utilidad en sede jurídico penal", Polít. crim., vol. 8, no 16 (2013), pp. 544 - 573, p. 547, en: http://www.politicacriminal.cl/Vol_08/n_16/Vol8N16A6.pdf, [visitado el 12.07.2016].

${ }^{98}$ NIETO MARTÍN, "Problemas fundamentales del cumplimiento", cit. nota no 2, p. 39.
} 
NEIRA, Ana María. "La efectividad de los criminal compliance programs como objeto de prueba en el proceso penal".

Sin embargo otra parte de la doctrina califica la existencia de un programa idóneo y eficaz como circunstancia eximente de la responsabilidad ${ }^{99}$, cuya prueba recaería, por lo tanto, según reglas procesales generalmente aceptadas, en la defensa.

Se observa, por lo tanto, que las opiniones son dispares y el tema es controvertido y de difícil solución. Ahora bien, llama la atención que, en tales argumentaciones, ni la doctrina y ni la jurisprudencia españolas hagan prácticamente distinción entre los dos sistemas de imputación de responsabilidad penal de las personas jurídicas que, cuando menos, las leyes italiana y española establecen de forma claramente diferenciada, según el delito haya sido cometido por un sujeto apical o por un subalterno. En este sentido, la doctrina italiana es la única que reconoce claramente, por venir casi impuesto por la literalidad de su regulación, que cuando delinquen los sujetos apicales, se invierte la carga de la prueba y es la entidad la que ha de probar que contaba con un modelo de prevención de delitos idóneo y eficaz ${ }^{100}$.

Para abordar el tema desde esta perspectiva, esto es, distinguiendo dos modelos de imputación, según si delinque un dirigente de la entidad o un subalterno, resulta relevante uno de los argumentos empleados por la FGE para hacer recaer sobre la organización la carga de acreditar la eficacia de su modelo de prevención de delitos. Se trata de la lógica de la prueba por indicios. En este sentido, se argumenta que "la atribución a la persona jurídica de la carga de la prueba deriva (...) del hecho de que la propia comisión del delito opera como indicio de la ineficacia del modelo y que, sobre esta base, cabría exigir a la persona jurídica una explicación exculpatoria que eliminara el efecto incriminatorio del indicio". Si bien, a renglón seguido, la Fiscalía matiza, y aquí está la clave de lo que se expondrá a continuación, que, mientras "un delito puntualmente cometido por un empleado no tiene gran carga indiciaria para desmontar la idoneidad del modelo, no sucede lo mismo con otras conductas criminales autorizadas o toleradas por el órgano de administración, que se han extendido en la empresa o han tenido larga duración". Pues bien, esta interpretación, es extensible, en mi opinión, tanto a la regulación italiana, como a la chilena y a la española, si bien a través de razonamiento parcialmente diversos.

3.4.2. La distribución de la carga de la prueba según quien sea el autor del delito base. El juego de las presunciones.

a) Si el delito fue cometido por sujetos "apicales" o con poderes de representación, dirección o supervisión.

Cuando los presuntos autores del delito sean los representantes legales de la entidad, aquellos autorizados para tomar decisiones en su nombre o quienes ostentan facultades de dirección, organización o control dentro de la misma, en principio, de acuerdo con las regulaciones española e italiana, a la acusación le bastará con probar que tales individuos cometieron el hecho de referencia, actuando en nombre o por cuenta de la entidad y en su beneficio directo o indirecto, sin que se exija específicamente el incumplimiento de los

\footnotetext{
${ }^{99}$ GUTIÉRREZ PÉREZ, Elena, "Los compliance programs como eximente o atenuante de la responsabilidad penal de las personas jurídicas: la eficacia e idoneidad como principios rectores tras la reforma de 2015", Revista General de Derecho Penal, núm. 24 (2015).

${ }^{100}$ ALBERICI Adalberto; BARUFFI Paolo; IPPOLITO Mario, et. al., Il modello di organizzazione gestione e controllo di cui al D. Lgs. 231. Profili metodologici e soluzioni operativi, Milán: Giuffrè, 2008, pp. 73-75.
} 
deberes de supervisión y dirección, como ocurre cuando delinquen los subalternos (art. 31 bis 1 b) CP y art. 7.1 D. Lgs. 231).

En este sentido, cabe afirmar que, cuando quien actúa es un alto cargo, se presume que el delito es expresión, directa o indirecta de la política social del ente promovida por su vértice $^{101}$, como consecuencia de la identificación orgánica que se produce entre la persona jurídica y sus órganos, entendidos, respectivamente, como el todo y la parte, y no como dos sujetos diferenciados ${ }^{102}$, sin que ello vulnere la presunción de inocencia de la entidad o el principio de culpabilidad. Tal argumentación parte de que la culpa objetiva o por el hecho de otro no puede entenderse en los mismos términos cuando se habla de persona físicas y cuando se habla de personas jurídicas, en tanto que la ficción que constituyen estas últimas se sustenta, precisamente, en su actuación a través de sus órganos, con lo que el acto del administrador o el representante, actuando como tal, resulta inescindible del actuar de la entidad.

La supuesta fricción de tal regla de identificación de la entidad y sus altos cargos con la presunción de inocencia o con el principio de culpabilidad penal quedaría suficientemente superada con la teoría de la identificación orgánica ("immedesimazione organica") ${ }^{103}$, así como con la excepción que para tal regla general supone el hecho de que la entidad pueda desligar su responsabilidad de las actuaciones de sus representantes, cuando la conducta individual se haya perpetrado como un plan preconcebido para burlar los controles preventivos de la organización (art. 31 bis $2.3^{\circ} \mathrm{CP}$ y art. 6.1.c) D. Lgs. 231). En definitiva, este modelo de trasferencia de responsabilidad, calificado por algunos de vicarial, está basado en la doctrina del alter ego, en virtud de la cual, a mayor implicación de los altos dirigentes en el hecho criminal, mayor debe ser el reproche de la persona jurídica, por cuanto son aquellos quienes encarnan a la entidad y quienes, en la práctica, diseñan y ejecutan la política empresarial ${ }^{104}$. Esta doctrina se inspira, a su vez, en las teorías organicistas propias del Derecho Administrativo, que identifican la actuación de los altos cargos de la organización con la de la propia organización ${ }^{105}$

La responsabilidad organizativa se derivaría de la implicación en la comisión del delito de aquellos que tienen, precisamente, el deber de controlar los riesgos delictivos en la entidad.

\footnotetext{
${ }^{101}$ RIGO, Fabrizio, "Il giudizio” en: AA.VV., La responsabilità amministrativa degli enti. D.lgs. 8 giugno 2001, n. 231, Milán: Ipsoa, 2002, pp. 351- 377, p. 362.

102 En este sentido, GUTIÉRREZ DE CABIEDES Y FERNÁNDEZ HEREDIA, Eduardo, Estudios de Derecho procesal, Pamplona: Eunsa, 1974, pp. 264-270, señala que no se puede calificar de representación la relación entre la sociedad y sus órganos porque no son dos personas, sino que el órgano integra jurídicamente a la persona jurídica, siendo su cauce normal de actuación.

${ }^{103}$ FERRUA, Paolo, "Il processo penale contra gli enti: incoerenze e anomalie nelle regole di accertamento", en GARUTI, Giulio (Dir.) Responsabilità degli enti per illeciti amministrativi dipendenti da reato, Padova: Cedam, 2002, pp. 223-242, p. 233.

${ }^{104}$ FGE, Circular 1/2011, p. 45.

105 RIGO, "Il giudizio". cit. nota $\mathrm{n}^{\mathrm{o}} 101$, p. 362; Igualmente, relacionado con este entendimiento de la responsabilidad penal de las personas jurídicas, está el high managerial test, previsto en el Código Penal Modelo americano, que imputa a la entidad los delitos autorizados, solicitados, ordenados, ejecutados o tolerados imprudentemente por el Consejo de Administración o por un alto directivo. Al respecto, véase GÓMEZ-JARA DÍEZ, Carlos, La responsabilidad penal de las empresas en los EE.UU, Madrid: Ramón Areces, 2006, pp. 50-52.
} 
NEIRA, Ana María. "La efectividad de los criminal compliance programs como objeto de prueba en el proceso penal".

Tal protagonismo de los sujetos apicales en el ilícito penal provoca que no sea preciso exigir una prueba específica sobre la eventual omisión de las obligaciones de vigilancia y control, si bien, a pesar de ello, cabe sostener que la persona jurídica responde conforme a su propia culpabilidad, deducida, con carácter iuris tantum, de ciertas actuaciones de sus dirigentes.

El fundamento empírico de tal presunción de culpabilidad en contra de la persona jurídica radica en que son los altos cargos de la entidad los responsables de diseñar sus estrategias y políticas, de fomentar una cultura cumplidora de la legalidad en su seno y de asumir la dirección y supervisión de su actividad. Por eso, cuando tales sujetos comenten un delito, difícilmente podrá sostenerse que se han cumplido los deberes de dirección y control o que la entidad estaba comprometida con el cumplimiento del Derecho. En este sentido, es necesario poner en valor, una vez más, la importancia del compromiso de la alta dirección con la cultura de cumplimiento normativo, para que esta sea tomada en serio y comprendida como una estrategia de la organización.

La FGE señala que "cualquier programa eficaz depende del inequívoco compromiso y apoyo de la alta dirección para trasladar una cultura de cumplimiento al resto de la compañía”. Por eso,

"si son los principales responsables de la entidad quienes incumplen el modelo de organización y de prevención o recompensan o incentivan, directa o indirectamente a los empleados que lo incumplen, difícilmente puede admitirse que exista un programa eficaz, que refleje una verdadera cultura de respeto a la ley en la empresa, de tal modo que, en estos casos, los Sres. Fiscales presumirán que el programa no es eficaz"106.

Por su parte, Nieto Martín, desde una perspectiva similar, afirma que la comprobación de la eficacia en abstracto del programa de cumplimiento tiende, sobre todo, a constatar si desde la dirección de la empresa se han hecho esfuerzos serios por crear una cultura de la legalidad y establecer controles apropiados, por eso, cuando los administradores o altos directivos aparecen implicados en el delito, tales esfuerzos de cumplimiento no resultan creíbles y existe una presunción de que la empresa no está correctamente organizada ${ }^{107}$.

A estos efectos, también resulta relevante llamar la atención sobre otra diferencia observada entre la regulación española, idéntica a la italiana en este punto, y la chilena. En Chile, la Ley 20.393 hace recaer sobre la propia organización el deber de cumplir con los deberes de dirección y supervisión, ya que usa la expresión "por parte de ésta", sin personalizar tales deberes en los administradores o directivos. Sin embargo, la regulación española, inspirada en el D. Lgs. 231, hace recaer tales deberes en las personas físicas con poder de representación, decisión, organización o control en la organización, esto es, en los sujetos apicales a los que se refiere el art. 31 bis 1) CP y el 6 D. Lgs. $231^{108}$. Por lo tanto, de la

\footnotetext{
${ }^{106}$ FGE, Circular 1/2016, p. 63.

${ }^{107}$ NIETO MARTÍN, "Problemas fundamentales del cumplimiento", cit. nota no 2, pp. 39-40.

108 En este sentido, la FGE, Circular 1/2016, pp. 7-8, indica que al referirse el art. 31 bis 1 b) CP a la circunstancia de "haberse incumplido por aquellos" los deberes de control, el precepto remite necesariamente a las personas físicas de la letra a), esto es, a "aquellos [...] autorizados para tomar decisiones" en nombre de la entidad. La FGE argumenta que, de haber pretendido el legislador, referir el control a las personas jurídicas
} 


\section{Polít. crim. Vol. 11, No 22 (Diciembre 2016), Art. 5, pp. 467-520. \\ [http://www.politicacriminal.cl/Vol_11/n_22/Vol11N22A5.pdf]}

implicación de tales sujetos en el delito cabrá deducir de forma prácticamente automática que los controles no existían o, cuando menos, que no estaban siendo efectivamente aplicados.

En este escenario, en el cual el incumplimiento de los deberes de dirección y supervisión se deduce de la comisión del delito por ciertos individuos, el debido cumplimiento de las obligaciones de control opera, y de hecho así se establece en algunas regulaciones legales, como un hecho impeditivo de la responsabilidad de la entidad, cuya prueba corresponde a la defensa ${ }^{109}$ la cual, en orden a evitar la condena, debe probar la eficacia y la vigencia de su modelo de organización y gestión orientado a la prevención delictiva, desvirtuando así la presunción de culpabilidad que pesa sobre ella. La efectiva implementación del modelo se erige, por lo tanto, en una circunstancia eximente que, como regla general, al igual que las atenuantes, debe ser probada por la defensa ${ }^{110}$.

El sentido de la carga de la prueba se deduce, en la regulación española, de la literalidad del $\mathrm{CP}$, que dispone que, cuando el delito fue cometido por un sujeto apical, la persona jurídica quedará exenta de responsabilidad si se cumplen ciertas condiciones (art. 31 bis $2 \mathrm{CP}$ ), entre otras la adopción de un determinado modelo de organización y gestión, señalando además que, si tales condiciones sólo se acreditan parcialmente, la entidad resultará condenada, aunque podrá ver atenuada su pena (art. 31 bis 2 in fine $\mathrm{CP})^{111}$. Por su parte, la regulación italiana es todavía más precisa en este aspecto señalando que, en caso de que el delito haya sido cometido por un sujeto apical, el ente no responde si prueba ciertos extremos, entre los que se encuentra el haber adoptado e implementado un modelo

indudablemente se habría utilizado el pronombre en femenino. Además, añade, acertadamente, que tal interpretación es plenamente conforme con el tenor literal de las correspondientes Decisiones Marco y Directivas de la Unión Europea que, para ciertos delitos, vienen a regular la responsabilidad de las personas jurídicas y que invariablemente las hacen responsables cuando la falta de supervisión o control por parte de una de las personas con poder de representación en la organización haya hecho posible que una persona sometida a su autoridad cometa una infracción determinada. Al respecto, pueden verse el art. 5 de la Directiva 2011/36/UE del Parlamento Europeo y del Consejo, de 5 de abril de 2011 relativa a la prevención y lucha contra la trata de seres humanos y a la protección de las víctimas; el art. 10 de la Directiva 2013/40/UE del Parlamento Europeo y del Consejo de 12 de agosto de 2013, relativa a los ataques contra los sistemas de información o el art. 6 de la Directiva 2014/62/UE del Parlamento Europeo y del Consejo de 15 de mayo de 2014 , relativa a la protección penal del euro y otras monedas frente a la falsificación.

${ }^{109}$ FERRUA, "Il processo penale contra gli enti", cit. nota ${ }^{\circ} 103$, p. 231.

${ }^{110}$ STS (Sala 2a , Sección 1 ${ }^{\text {a }}$ ) no 277/2014, de 7 de abril, RJ $2014 \backslash 2181$, fundamento jurídico $5^{\circ}$, entre otras; También podríamos acudir, como propone, NIETO MARTÍN, "Problemas fundamentales del cumplimiento", cit. nota $n^{\mathbf{0}}$ 2, p. 32, a las categorías, más sencillas, de Derecho Penal internacional, de ofensa y defensas, encuadrándose, en tal caso, la vigencia y eficacia del modelo de prevención de delitos en la categoría de las defensas, en tanto que motivos, materiales o procesales, que pueden llevar a la exclusión de la responsabilidad.

${ }^{111}$ La FGE interpreta esta disposición legal señalando que la acreditación parcial no se refiere al estándar de prueba exigible, sino que hace referencia a la cuestión penal, es decir, al caso en que, de acuerdo con el estándar habitual de prueba, "no concurren todos los elementos y requisitos que indica el apartado (...). Dicho de otro modo, la acreditación parcial no implica una rebaja de las exigencias probatorias sino sustantivas, esto es, que el modelo presenta algunos defectos o que solo se ha acreditado que hubo cierta preocupación por el control, un control algo menos intenso del exigido para la exención plena de responsabilidad penal, pero suficiente para atenuar la pena" (Circular 1/2016, p. 46). 
NEIRA, Ana María. "La efectividad de los criminal compliance programs como objeto de prueba en el proceso penal".

organizativo idóneo para prevenir delitos de la especie del que se ha verificado (art. 6.1 D. Lgs. 231) ${ }^{112}$.

Una parte de la doctrina italiana entiende que tal régimen implica una suerte de inversión de la carga de la prueba ${ }^{113}$. En esta línea, se argumenta que la presunción de culpabilidad organizativa y la dificultad de neutralizar tal presunción por el ente, choca con el principio de culpabilidad sobre el plano penal ${ }^{114}$. Sin embargo, no cabe olvidar que, siendo los sujetos apicales los encargados de controlar y supervisar que la persona jurídica se encuentra adecuadamente organizada y que no asume, con sus actividades, riesgos penales excesivos, resulta legítimo que, de sus actuaciones delictivas, perpetradas en el seno de la entidad, actuando en su nombre o por su cuenta y en su beneficio, se deduzca la responsabilidad del ente por defectuosa organización o por deficiencias en el control de los riesgos penales ${ }^{115}$.

Por su parte, la regulación chilena señala que las personas jurídicas serán responsables de ciertos delitos

"cometidos directa e inmediatamente en su interés o para su provecho, por sus dueños, controladores, responsables, ejecutivos principales, representantes o quienes realicen actividades de administración y supervisión, siempre que la comisión del delito fuere consecuencia del incumplimiento, por parte de ésta, de los deberes de dirección y supervisión" (art. 3 Ley 20.393).

En este caso, la regulación sí exige, específicamente, como un elemento constitutivo de la responsabilidad de la persona jurídica, esto es, como parte de la ofensa, el incumplimiento de los deberes de dirección y supervisión, aun cuando los autores del delito sean los altos cargos de la entidad. Por lo tanto, será preciso que la investigación y la prueba de su

${ }^{112}$ El D. Lgs. 231 emplea términos idénticos a los inicialmente contenidos en el Anteproyecto de Ley Orgánica de modificación del CP, firmado por el Ministro de Justicia español, con fecha de 4 de abril de 2013, posteriormente modificada durante la tramitación parlamentaria. El cambio de redacción producido durante la tramitación parlamentaria de la Ley Orgánica 1/2015, de 30 de marzo, que modificó el CP, y que optó por eliminar la expresión "si prueba que", se debe, seguramente, al intento de evitar introducir una norma de carácter procesal, relativa a la distribución de la carga de la prueba, en la regulación penal. Sin embargo, a efectos prácticos, el cambio es más simbólico que real, en tanto que las circunstancias que deben concurrir para que la entidad logre quedar exenta de responsabilidad, a pesar de que hayan delinquido sus administradores, representantes o los encargados de las funciones de organización y control, no han variado y, tratándose de una circunstancia eximente, la carga de introducirla en el proceso seguirá recayendo en la defensa.

${ }^{113}$ FERRUA, Paolo, "Le anomalie del regime probatorio nel processo penale contro gli enti: onere della prova e incompatibilità a testimoniare", Giurisprudenza italiana, $\mathrm{n}^{\circ} 7$ (especial La responsabilità degli enti da reato, otto anni dopo) (2009), pp. 1845-1848.

${ }^{114}$ Críticas similares son esgrimidas por CERESA GASTALDO, Massimo, "Processo penale e accertamento della responsabilità amministrativa degli enti: una innaturale ibridazione", Cassazione Penale, vol. 49, núm. 5 (2009), pp. 2232-2240; GARUTI, Giulio, "Il processo "penale" agli enti" en: AA.VV., SPANGHER, Giorgio, (Dir.), Trattato di procedura penale, vol. VII, Modelli differenziati di accertamento, Tomo I, Turín: Utet Guiridica, 2011, pp. 1029-1135, p. 1118

${ }^{115}$ Comisión Lattanzi para la aplicación del artículo 11 Ley 300/2000 en materia de responsabilidad de la persona jurídica, constituida por Decreto Legislativo de 15 de noviembre del año 2000. 
responsabilidad abarquen tal extremo, ya que si los deberes se han cumplido la conducta será atípica ${ }^{116}$.

Ahora bien, en mi opinión, también en Chile, acreditada la implicación de los altos cargos en la comisión del delito (hecho indicio) cabe inferir que los deberes de dirección y supervisión se han incumplido (hecho consecuencia), ya que no resulta lógico pensar que quien dolosamente delinquió, al mismo tiempo, pudo actuar diligentemente en la gestión de los riesgos delictivos de la organización.

En definitiva, la implicación de los altos cargos en la comisión del delito permite presumir, al menos iuris tantum, que existe un escaso compromiso de la entidad con el cumplimiento de la legalidad, de lo cual cabe deducir, cuando menos indiciariamente, que el sistema de dirección y supervisión no estaba funcionando de forma adecuada, ya que los encargados de tales tareas habrían actuado de forma contraria a la legalidad. Esto resulta, si cabe más evidente, cuando es el encargado de cumplimiento el que está implicado en la actuación delictiva, supuesto en el cual, difícilmente, podrá quedar la persona jurídica exenta de responsabilidad $^{117}$.

Ahora bien, incluso en el caso de que sean los directivos o los miembros del consejo de administración los que cometan el delito, ya por acción, ya por omisión, existe la posibilidad de que el ente no responda penalmente si se acreditan ciertas circunstancias que denotan su alto compromiso con la legalidad, demostrando que, a pesar de haber puesto toda la diligencia debida en la evitación de delitos, a través de planes de formación y capacitación de su personal y de instrumentos adecuados para prevenir y detectar irregularidades, uno de sus dirigentes realizó sus propósitos delictivos, burlando los controles implementados por la organización y actuando en contra de sus políticas de cumplimiento.

Por ejemplo, los tribunales italianos declararon exenta de responsabilidad a una entidad cuyos directivos habían maquillado el balance de la entidad para tranquilizar al mercado financiero, difundiendo datos sobre las condiciones patrimoniales y financieras de la entidad, tras haberlos falseado. En tal caso, aunque la actuación delictiva fue perpetrada por el presidente del consejo de administración y el consejero delegado, el comportamiento de la empresa no se consideró punible porque tales individuos actuaron eludiendo el correspondiente modelo de organización de la entidad. En este sentido, argumenta el Tribunal italiano que, si hubiesen seguido el proceso previsto en el modelo, habría sido imposible para los imputados actuar de ese modo. Por lo tanto, el comportamiento ilícito no se debería a un modelo organizativo erróneo, sino a un comportamiento de los directivos contrario a las reglas internas reflejadas en tal modelo ${ }^{118}$.

\footnotetext{
${ }^{116}$ Cfr. PIÑA ROCHEFORT, Modelos de prevención, cit. nota ${ }^{\circ} 45$, p. 7.

117 De hecho, según FGE, Circular 1/2016, p. 49, del art. 31 bis $4^{\circ} \mathrm{CP}$ se deduce que "si el oficial de cumplimiento omite sus obligaciones de control, la persona jurídica en ningún caso quedará exenta de responsabilidad penal'.

118 Sentencia del Tribunal de Milán, Juez para la Investigación Preeliminar E. Manzi, 17 de noviembre de 2009 (conocido como caso "impregilo"). Pronunciamiento confirmado por la Corte de Apelación de Milán n 1824 , de 21 de marzo de 2012.
} 
NEIRA, Ana María. "La efectividad de los criminal compliance programs como objeto de prueba en el proceso penal".

De lo dicho hasta el momento, se concluye que, una vez probado que uno de los dirigentes de la entidad cometió un delito en su nombre y en su beneficio, de tal hecho cabe deducir, al menos indiciariamente, que no se cumplieron los deberes de prevención delictiva que incumben a la organización. Ahora bien, tal presunción admite prueba en contrario, por lo que, en tal caso, la entidad, para quedar exenta de responsabilidad, deberá probar que contaba con modelos de organización y gestión idóneos para prevenir delitos de la naturaleza del supuestamente cometido, que existía un órgano de control, con poderes autónomos de iniciativa y control respecto de la administración de la entidad y, en el caso de las regulaciones española e italiana, que el sujeto apical que cometió el delito lo hizo esquivando las barreras de prevención que la organización tenía implementadas para prevenir o minimizar el riesgo de comisión de delitos en su seno, esto es, que engañó, dolosamente, al encargado de prevención.

En definitiva, probada la comisión de un delito por los dirigentes de la entidad, actuando en su nombre y en su beneficio, parece haber indicios incriminatorios suficientes contra la persona jurídica que, cuando menos, exigirían una actuación de la entidad para acreditar la eficacia de su programa de cumplimiento. Así pues, cuando las pruebas de la acusación son suficientes para requerir una respuesta o una explicación que el acusado debería estar en condiciones de dar, de acuerdo con la doctrina del TEDH, si este adopta una actitud pasiva o ejercita su derecho al silencio, de tal comportamiento procesal se puede deducir, en base al sentido común, que no existe ninguna explicación posible y que el acusado es culpable $^{119}$. Es esta dinámica de la prueba por indicios la que tiene como consecuencia que, en el caso en que se considere probado que los dirigentes de la entidad están implicados en el delito, se presuma la ineficacia del programa de cumplimiento y que, por lo tanto, su eficacia deba ser acreditada por la defensa.

Quizás podría resultar adecuado positivizar tal presunción, al estilo de lo que hace la regulación italiana, exigiendo, para el caso de que delincan los sujetos apicales, que el ente pruebe que contaba con un programa eficaz que fue burlado por los autores del delito o, al estilo de la regulación española, omitiendo como requisito típico el incumplimiento de los deberes de supervisión y dirección para el caso de que hayan sido los altos cargos los que hayan delinquido. De esta forma, distinguiendo en la propia ley los dos sistemas de imputación según el puesto que ocupa en la entidad el autor del delito, no se erosiona la presunción de inocencia de la entidad, en tanto que se parte de un nexo lógico y no arbitrario, consistente en entender que cuando los encargados de dirigir y controlar están implicados en el delito, los deberes de dirección y organización no se han cumplido y, sobre todo, se respeta, en mayor medida, el principio de legalidad, en su faceta de previsibilidad.

En cualquier caso, lo que obviamente no especifican, ni deberían especificar, las regulaciones analizadas es la "cantidad" de prueba necesaria para convencer al Juez de que

\footnotetext{
${ }^{119}$ Sentencia del Tribunal Europeo de Derechos Humanos, de 8 de febrero de 1996, caso John Murray contra el Reino Unido.
} 
el ente actuó diligentemente en sus deberes de prevención delictiva ${ }^{120}$. Esta es una cuestión de estándar de prueba y no de carga de la prueba.

Pues bien, para evitar problemas de legitimidad constitucional en relación con la presunción de inocencia, se debe entender que cuando una eximente es razonablemente acreditada por el acusado, haciendo nacer dudas razonables en el juzgador sobre su concurrencia, deberá acordarse su absolución ${ }^{121}$, de tal forma que, en aplicación del principio in dubio pro reo, las dudas fundadas sobre la vigencia de la eximente, se equiparen a la consecución de la prueba positiva sobre su existencia. En este sentido, cabe argumentar que "si la postura de la defensa es plausible, razonable, quiere decir que la otra tesis, la del fiscal, no ha podido superar el estándar exigido y, en consecuencia, su prueba no va más allá de la duda razonable" ${ }^{122}$.

En otras palabras, para obtener su absolución, bastaría con que el ente acusado hiciese surgir una duda razonable en el juzgador sobre la existencia y la vigencia de un modelo de prevención de delitos eficaz ${ }^{123}$, mientras que la absoluta falta de prueba al respecto o la existencia de prueba en contrario, comportaría la condena del ente, en su caso, con la correspondiente atenuación de responsabilidad. En definitiva, a la hora de decidir sobre la culpabilidad o la inocencia de la entidad, cualquier duda razonable, ya sobre la ofensa, ya sobre las defensas, debiera resolverse en favor del acusado ${ }^{124}$.

\section{b) Si el delito fue cometido por los subalternos.}

Al contrario de lo que ocurre en el supuesto en que sean los altos cargos de la entidad los autores del delito, cuando quien delinque es un subordinado, esto es, un sujeto sin poder de

\footnotetext{
${ }^{120}$ En términos similares, aunque en relación con la regulación italiana, se pronuncia CHIMICHI, Serena, "Il processo penale a carico degli enti: il quantum della prova de la colpa di organizzazione", Diritto penale e processo, vol. 5 (2004), pp. 617-621, p. 620.

${ }^{121}$ En este sentido, tal y como afirma la FGE, Circular 1/2016, p. 46, la referencia a la "acreditación parcial" de las circunstancias que integran la eximente de responsabilidad (art. 31 bis $2.4^{\circ} \mathrm{CP}$ ) "no implica una rebaja de las exigencias probatorias sino sustantivas, esto es, que el modelo presenta algunos defectos o que solo se ha acreditado que hubo cierta preocupación por el control, un control algo menos intenso del exigido para la exención plena de responsabilidad penal, pero suficiente para atenuar la pena".

${ }^{122}$ CARNEVALI RODRÍGUEZ, Raúl; CASTILLO VAL, Ignacio, "El estándar de convicción de la duda razonable en el proceso penal chileno, en particular la relevancia del voto disidente", Ius et Praxis, vol. 17, ${ }^{\circ}$ 2 (2011), pp. 77-118, p. 117, en: http://www.scielo.cl/pdf/iusetp/v17n2/art05.pdf [visitado el 12.07.2016]

${ }^{123}$ En términos similares, aunque en relación con la regulación italiana se pronuncia, VARRASO, Gianluca, Il procedimento per gli illeciti amministrativi dipendenti da reato, Milán: Giuffrè, 2012, pp. 365-367.

${ }^{124}$ Así se deduce claramente del art. 340 CPP chileno al señalar que la convicción del tribunal, más allá de toda duda razonable, no alcanzará sólo a la comisión del hecho sino también a la culpabilidad y a la punibilidad del acusado. También del art. 330.3 CPP italiano, el cual dispone que la duda sobre una causa de justificación o sobre una causa personal de exclusión de la punibilidad debe conducir a una sentencia absolutoria. Por su parte, la LECrim no hace referencia expresa al principio in dubio pro reo, si bien, es reiterada la jurisprudencia del TS que lo deriva del art. 24.2 CE, aunque su ámbito de aplicación se limita a los casos en que el Tribunal sentenciador reconoce la existencia de una duda sobre la concurrencia de alguno de los elementos integradores del tipo y opta por la solución más perjudicial para el acusado. Por lo tanto, sólo aplica en casos de duda, pero existiendo prueba de cargo suficiente y válida, si el Tribunal sentenciador expresa su convicción sin duda razonable alguna, el referido principio carece de aplicación (STS (Sala 2a Sección 1a) no 827/2015, de 15 de diciembre, RJ 2015\6624).
} 
NEIRA, Ana María. "La efectividad de los criminal compliance programs como objeto de prueba en el proceso penal".

decisión, control, administración o representación en la entidad, las regulaciones española e italiana exigen probar que su actuación delictiva, además de haberse realizado en el ejercicio de las actividades sociales o por cuenta del ente y en su beneficio, directo o indirecto, ha sido posible por el incumplimiento grave de los deberes de dirección, supervisión, vigilancia o control, por parte de las personas u órganos responsables de tales funciones, atendidas las concretas circunstancias del caso. Esto se traduce en que la entidad sólo responde si, a través de la omisión de sus deberes de control, ha incurrido en un riesgo excesivo que, posteriormente, se ha materializado en la comisión de un delito en su beneficio, por alguno de sus empleados, en el ejercicio de sus funciones en la organización.

La diferencia más relevante en relación con el supuesto anterior radica en que, en este caso, el incumplimiento del deber de control no puede deducirse de la comisión del delito por un miembro de la entidad que no ostenta poderes de administración, dirección o supervisión, ya que, este acto, por si solo, no tiene fuerza indiciaria suficiente para incriminar a la entidad. Por eso, adicionalmente, se requiere una prueba de cargo, específica y suficiente, que acredite la falta de controles en relación con el área de actividad en que presuntamente se cometió el ilícito, la inadecuada o confusa distribución de responsabilidades entre los miembros de la entidad, la falta de supervisión sobre los subalternos, la insuficiencia o inexistencia del sistema de sanciones para quienes incumplan el modelo de prevención, la carencia de medidas apropiadas para detectar conductas delictivas u otras características de la organización, de las cuales quepa deducir que la entidad incurrió, en el desarrollo de su actividad, en riesgos excesivos que, finalmente, se han materializado en la comisión del delito perseguido. Solo de esta forma, cabe afirmar que la responsabilidad de la persona jurídica se basa en un hecho propio de la entidad y no en la mera trasmisión de la responsabilidad derivada de las actuaciones de sus miembros.

En este caso, por lo tanto, la acusación debe probar la falta de una adecuada supervisión de los sujetos apicales sobre sus subordinados que, en el caso concreto, haya permitido a estos últimos cometer un delito por cuenta y en beneficio de la entidad ${ }^{125}$. Ahora bien, tal omisión del control debido, aun cuando no pueda determinarse específicamente para la concreta actuación delictiva enjuiciada, puede inferirse de la ausencia de ciertas prácticas, protocolos, rutinas o mecanismos preestablecidos en orden a prevenir la comisión de ilícitos penales. Tal inferencia estaría en línea con lo previsto en la regla 406 de las Federal Rules of Evidence norteamericanas, al disponer que las pruebas de los hábitos de una persona o de la práctica rutinaria de una organización pueden admitirse para probar que en una ocasión particular la persona o la organización actuaron de acuerdo con ese hábito o

\footnotetext{
${ }^{125}$ Cfr. GASCÓN INCHAUSTI, Proceso penal y persona, cit., nota no 60, p. 146; Así mismo, MARTÍNEZ PÉREZ, Miriam; SANDE MAYO, María Jesús, "La responsabilidad penal de las personas jurídicas", en: CASTILLEJO MANZANARES, Raquel (Dir.); SANDE MAYO, María Jesús (Coord.) Temas actuales en la persecución de los hechos delictivos, Madrid: La Ley, 2012, pp. 373-396, p. 394, sostienen que la carga de la prueba sobre el defecto de organización, en tanto que hecho constitutivo de la responsabilidad penal del ente, corresponde a la acusación; JUANES PECES, Ángel, "Necesidades en la regulación procesal de la responsabilidad penal de las personas jurídicas", en: AA. VV., Reforma penal: personas jurídicas y tráfico de drogas; Justicia restaurativa, Cuadernos penales de José María Lidón, $\mathrm{n}^{\circ}$ 8, Bilbao: Publicaciones de la Universidad de Deusto, 2011, pp. 39-44, p. 44.
} 
práctica rutinaria $^{126}$.

Por lo tanto, a los efectos de distribuir la carga de la prueba, cuando el autor del delito no es un alto cargo de la entidad, la acusación deberá practicar prueba de cargo suficiente para acreditar ese incumplimiento de los deberes de supervisión, vigilancia y control de los superiores sobre sus subordinados, ya a través de la verificación de que no existe un programa de prevención de delitos vigente, ya a través de la prueba sobre sus fallas o su falta de idoneidad o eficacia, sin que la comisión de un delito por cualquier empleado sin poderes autónomos de dirección y supervisión resulte evidencia suficiente a tal fin.

Por su parte, la defensa podrá contrarrestar tales pruebas acreditando la existencia de medidas adecuadas de prevención delictiva adoptadas y efectivamente implementadas con anterioridad a la comisión del ilícito. Dada la redacción legal de la ley italiana, que señala que la inobservancia de las obligaciones de control se excluye en todo caso si existían modelos de organización y gestión idóneos para la prevención del delito cometido (art. 7.2 D. Lgs. 231), parece que esta presunción no admite prueba en contrario en aquel país. Sin embargo, tal y como se viene argumentando, no parece adecuado limitar la actividad valorativa del Juez a comprobar que el programa de cumplimiento respeta formalmente los requisitos exigidos por la ley, debiendo centrarse su juicio jurisdiccional en determinar si, en el caso concreto, la persona jurídica puso la diligencia debida o exigible para evitar la comisión del delito enjuiciado $^{127}$, o si, por el contrario, incurrió en un riesgo excesivo, al no controlar adecuadamente los peligros propios de su actividad.

Por otra parte, si la defensa consigue hacer nacer en el juzgador una duda razonable sobre la concurrencia, en el caso concreto, de esa omisión de control, sobre el incumplimiento de los deberes de supervisión o sobre la existencia de mecanismos idóneos y eficaces, desde una perspectiva ex ante, para evitar la comisión de delitos idénticos o análogos al cometido, procederá la absolución del ente ya que, en virtud del derecho a la presunción de inocencia y del principio in dubio pro reo, tanto la falta de prueba de cargo suficiente sobre un

\footnotetext{
${ }^{126}$ En concreto, la regla probatoria del ordenamiento estadounidense señala que 'Evidence of a person's habit or an organization's routine practice may be admitted to prove that on a particular occasion the person or organization acted in accordance with the habit or routine practice. The court may admit this evidence regardless of whether it is corroborated or whether there was an eyewitness"; Pues bien, siguiendo la misma lógica, las regulaciones italiana y chilena también vinculan el cumplimiento de los deberes de supervisión, vigilancia y control, como elemento excluyente de la responsabilidad, con la existencia de modelos de organización y gestión eficaces para prevenir delitos Así pues, la ley italiana señala que, en todo caso, se excluye la omisión de tales deberes de control si el ente, antes de la comisión del delito, ha adoptado y ejecutado eficazmente un modelo de organización, gestión y control que resulte adecuado para prevenir delitos de la naturaleza del que fue cometido (art. 7.2 D. Lgs. 231). En la misma línea, la regulación chilena dispone que "Se considerará que los deberes de dirección y supervisión se han cumplido cuando, con anterioridad a la comisión del delito, la persona jurídica hubiere adoptado e implementado modelos de organización, administración y supervisión para prevenir delitos como el cometido (...)” (art. $3^{\circ}$ III Ley 20.393). Se trata de presunciones en las que el enlace entre el hecho indicio y el hecho presunto o indiciado aparece expresamente previsto en la ley.

${ }^{127}$ Tal y como señala SALVO ILABEL, Modelos de imputación penal, cit, nota n ${ }^{\circ}$ 48, p. 337, la adopción del modelo de prevención de delitos será analizada por el juez en relación con el delito concreto que ha dado lugar al proceso, por lo que su idoneidad y su capacidad para conjurar el riesgo delictivo se deberá examinar en relación con él y no en relación con todos los riesgos que enfrenta la actividad del ente.
} 
NEIRA, Ana María. "La efectividad de los criminal compliance programs como objeto de prueba en el proceso penal".

elemento de la ofensa, como la duda fundada sobre la concurrencia da una defensa excluyente de responsabilidad, impedirían dictar una sentencia condenatoria.

\section{Conclusiones.}

1. Un programa de cumplimiento normativo eficaz es aquel adaptado a las características de la organización y a los riesgos propios de su actividad, efectivamente implementado en la estructura organizativa del ente, a través de la adaptación de la empresa y de sus actividades a los principios y protocolos de actuación del programa y eficazmente supervisado y actualizado, de forma periódica, por un organismo que actúe con autonomía en relación con el órgano de administración de la entidad.

2. La empresa que cuenta con un modelo de prevención de delitos eficaz, de forma previa a la comisión del delito, pone de manifiesto que gestiona los riesgos propios de su actividad con la debida diligencia, en tanto que no incurre en riesgos excesivos desde el punto de vista penal y cuenta con mecanismos para controlar adecuadamente los riesgos en que incurre con su actividad, luego no debiera responder por los delitos cometidos por sus miembros.

3. La relación que existe entre los deberes de supervisión y control de la entidad, como núcleo del injusto que se le imputa, y la implementación efectiva de un programa de cumplimiento penal, implica que las pruebas orientadas a acreditar la existencia, vigencia y efectividad del programa son pertinentes en un eventual proceso penal en el que se pretenda determinar la responsabilidad penal de la persona jurídica y que, además, tales pruebas pueden ser de gran utilidad para la defensa.

4. Para introducir los programas de cumplimento normativo como prueba en un proceso penal es necesario combinar la prueba documental, aportando no sólo el diseño del modelo, sino también todos los documentos generados con su implementación y su ejecución, junto con las pruebas testificales de los directivos y trabajadores de la entidad y, en su caso, con las periciales, ya del auditor del programa o del certificador externo, ya del compliance officer u oficial de cumplimiento, que podría ser llamado como testigo o, en su caso, como testigo-perito, en atención a su integración en la entidad acusada y a sus conocimientos técnicos sobre gestión de riesgos, administración y dirección de empresas y compliance penal.

5. La certificación ex ante de la eficacia del programa de cumplimiento por una entidad independiente puede ser valorada como un elemento más a favor del compromiso de la entidad con el cumplimiento de la legalidad pero, en ningún caso, es una prueba autosuficiente de la eficacia del programa, la cual ha de ser valorada libremente por el órgano judicial junto con el resto de las pruebas practicadas en juicio, sobre todo si se toma en consideración que los procedimientos de certificación no se encuentran estandarizados. Por este motivo, la certificación sólo tendrá validez para acreditar la eficacia del programa cuando sirva para recopilar evidencias que acrediten la efectiva implementación del programa y cuando la entidad certificadora ofrezca garantías de independencia y profesionalidad. 
6. Teóricamente, a la acusación le corresponde probar que la persona jurídica, en la gestión de su actividad, ha incurrido en riesgos penales por encima del nivel jurídicamente aceptable y que, como consecuencia de tales riesgos excesivos, alguno de sus miembros ha podido cometer un delito. Acreditado lo anterior, la entidad, para desligarse de la actuación de sus miembros y quedar exenta de responsabilidad, debe probar que puso toda la diligencia debida para prevenir y detectar las conductas delictivas que pudieran producirse en el desarrollo de su actividad, ya a través de la implementación de un programa de cumplimiento que atienda a los requisitos preestablecidos por la ley, ya a través de otras medidas o instrumentos idóneos para prevenir y detectar irregularidades o infracciones como la supuestamente cometida.

7. En la práctica, ante la dificultad de acreditar procesalmente la relación de causalidad entre el incumplimiento de los deberes de supervisión o dirección que competen a la organización y la comisión del delito, se acude a la prueba por indicios, de tal forma que, acreditado un hecho base o indicio, cabe inferir, a través de un razonamiento deductivo, ya judicial, ya plasmado en la ley, que concurre el hecho consecuencia.

8. El hecho consecuencia que se pretende probar es el incumplimiento relevante de los deberes de control por parte de la entidad, como creador de riesgos delictivos excesivos que, finalmente, se materializan en un resultado lesivo para bienes jurídicos protegidos por la normativa penal. Pues bien, la cuestión que se plantea en este trabajo es que el hecho base varía según el delito haya sido cometido por los dirigentes de la entidad o por sus subordinados, carentes de poderes de dirección y supervisión.

Cuando son los sujetos con poder de decisión, dirección o supervisión en el seno de la entidad los que han cometido el delito, de tal hecho puede deducirse directamente que ha habido un incumplimiento de los deberes de dirección o supervisión. En tal caso, la ineficacia del programa se infiere indiciariamente o se deduce de la implicación de los altos cargos en el delito. Ahora bien, la entidad puede desacreditar tal presunción si demuestra que los directivos eludieron fraudulentamente sus controles orientados a prevenir y detectar conductas ilícitas, es decir, que quebrantaron las barreras de prevención específicas impuestas por la entidad para evitar la conducta realizada.

Cuando, por el contrario, son los subalternos los que cometieron el delito, el ejercicio insuficiente de las funciones de dirección y control por sus superiores o la insuficiencia o ineficacia de las medidas de prevención y detección de delitos implementadas por la organización, no pueden deducirse, en principio, de la mera comisión del delito por un empleado. Por eso, en este supuesto, será preciso que la acusación pruebe que no existían prácticas, protocolos, rutinas o mecanismos para prevenir la comisión de ilícitos penales o, en su caso, que los existentes eran inidóneos o ineficaces para prevenir delitos como el cometido, debiendo acreditar tal extremo más allá de cualquier duda razonable, a través del interrogatorio de directivos, empleados, así como del requerimiento o incautación de evidencias documentales sobre tales instrumentos preventivos.

9. En cualquier caso, en virtud del principio in dubio pro reo, el grado de convicción judicial requerido para dictar una sentencia condenatoria ha de ser suficiente para vencer la 
NEIRA, Ana María. "La efectividad de los criminal compliance programs como objeto de prueba en el proceso penal".

presunción de inocencia del acusado y ha de superar el estándar de la duda razonable. Por eso, si tras la práctica de la prueba, útil y pertinente, el juzgador alberga dudas sobre la responsabilidad del ente, ya en cuanto a la concurrencia de la ofensa, incluyendo, en su caso, la infracción de los deberes de dirección y supervisión de la entidad, ya en cuanto a la concurrencia de una defensa excluyente de responsabilidad, como sería la efectiva implementación de un programa de cumplimiento penal idóneo para prevenir el delito cometido, la entidad deberá ser absuelta. 
Polít. crim. Vol. 11, No 22 (Diciembre 2016), Art. 5, pp. 467-520.

[http://www.politicacriminal.cl/Vol_11/n_22/Vol11N22A5.pdf]

\section{LISTA BIBLIOGRÁFICA}

ALBERICI Adalberto, BARUFFI Paolo, IPPOLITO Mario, et. al., Il modello di organizzazione gestione e controllo di cui al D. Lgs. 231. Profili metodologici e soluzioni operativi, Milán: Giuffrè, 2008.

ARTAZA VARELA, Osvaldo, La empresa como sujeto de imputación de responsabilidad penal. Fundamentos y límites, Madrid: Marcial Pons, 2013.

"Sistemas de prevención de delitos o programas de cumplimiento. Breve descripción de las reglas técnicas de gestión del riesgo empresarial y su utilidad en sede jurídico penal", Polít. crim., vol. 8, nº 16 (2013), pp. $544-573$.

, "Programas de cumplimiento. Breve descripción de las reglas técnicas de gestión del riesgo empresarial y su utilidad jurídico-penal" en: MIR PUIG, Santiago; CORCOY BIDASOLO, Mirentxu; GÓMEZ MARTÍN, Víctor (Dirs.); HORTAL IBARRA, Juan Carlos; VALIENTE IBÁÑEZ, Vicente (Coords.), Responsabilidad de la empresa y compliance. Programas de prevención, detección y reacción penal, Montevideo-Buenos Aires: B de F, 2014, pp. 231-271.

BACIGALUPO ZAPATER, Enrique, "Responsabilidad penal y administrativa en las personas jurídicas y programas de "compliance" (A propósito del Proyecto de reformas del Código Penal de 2009)", Diario La Ley, núm. 7742, 9 de julio de 2010.

BELHADJ BEN GÓMEZ, Celia, "El testigo-perito, proposición y práctica de prueba. Distinción con el perito", Revista Aranzadi Doctrinal, núm. 2 (2014), pp. 1-6.

BERMÚDEZ MUÑOZ, Martín, "El futuro de la carga de la prueba en materia de responsabilidad", Revista Temas Jurídicos, Colombia: Colegio Mayor de Nuestra Señora del Rosario, $\mathrm{n}^{\circ} 11$ (1997) pp. 16-38.

BOCK, Dennis, "Compliance y deberes de vigilancia en la empresa", en: KUHLEN, Lothar; MONTIEL, Juan Pablo; ORTIZ DE URBINA GIMENO, Íñigo (Eds.) Compliance y teoría del Derecho Penal, Madrid: Marcial Pons, 2013, pp. 107-124.

CADOPPI, Alberto; GARUTI, Giulio; VENEZIANI, Paolo, Enti e responsabilità da reato, Turín: Utet Giuridica, 2010.

CARNEVALI RODRÍGUEZ, Raúl; CASTILLO VAL, Ignacio, "El estándar de convicción de la duda razonable en el proceso penal chileno, en particular la relevancia del voto disidente", Ius et Praxis, vol. 17, n⿳0 2 (2011), pp. 77-118.

CERESA GASTALDO, Massimo, "Processo penale e accertamento della responsabilità amministrativa degli enti: una innaturale ibridazione", Cassazione Penale, vol. 49, núm. 5 (2009), pp. 2232-2240.

COCA VILA, Ivó, "¿Programas de cumplimiento como forma de autorregulación regulada?” en: SILVA SÁNCHEZ, Jesús María (Dir.); MONTANER FERNÁNDEZ, Raquel (Coord.) Criminalidad de empresa y compliance. Prevención y reacciones corporativas, Barcelona: Atelier, 2013, pp. 43-76.

COLLADO GONZÁLEZ, Rafael, Empresas criminales. Un análisis de los modelos legales de responsabilidad penal de las personas jurídicas implementados en Chile y en España, Thomson Reuters: Santiago de Chile, 2013.

CHIMICHI, Serena, "Il processo penale a carico degli enti: il quantum della prova de la colpa di organizzazione", Diritto penale e processo, vol. 5 (2004), pp. 617-621. 
NEIRA, Ana María. "La efectividad de los criminal compliance programs como objeto de prueba en el proceso penal".

DOPICO GÓMEZ-ALLER, Jacobo, "Responsabilidad de personas jurídicas”, Memento Experto. Reforma Penal 2010. Ley Orgánica 5/2010, Madrid: Francis Lefebvre, 2010, pp. 11-38.

FERRUA, Paolo, "Il processo penale contra gli enti: incoerenze e anomalie nelle regole di accertamento", en: GARUTI, Giulio (Dir.) Responsabilità degli enti per illeciti amministrativi dipendenti da reato, Padova: Cedam, 2002, pp. 223-242.

"Le anomalie del regime probatorio nel processo penale contro gli enti: onere della prova e incompatibilità a testimoniare”, Giurisprudenza italiana, $\mathrm{n}^{\mathrm{o}} 7$ (especial La responsabilità degli enti da reato, otto anni dopo) (2009), pp. 1845-1848.

GALLEGO SOLER, José Ignacio, "Criminal compliance y proceso penal: reflexiones iniciales" en: MIR PUIG, Santiago; CORCOY BIDASOLO, Mirentxu; GÓMEZ MARTÍN, Víctor (Dirs.); HORTAL IBARRA, Juan Carlos; VALIENTE IBÁÑEZ, Vicente (Coords.), Responsabilidad de la empresa y compliance. Programas de prevención, detección y reacción penal, Montevideo-Buenos Aires: B de F, 2014, pp. 195-229.

GARCÍA CAVERO, Percy, Criminal Compliance, Lima: Palestra Editores, 2014.

GARCÍA MORENO, Beatriz, "Whistleblowing y canales institucionales de denuncia" en: NIETO MARTÍN, Adán (Dir.), Manual de cumplimiento penal en la empresa, Barcelona: Tirant lo Blanch, 2015, pp. 205-230.

GARUTI, Giulio, "Il processo "penale" agli enti” en: AA.VV., SPANGHER, Giorgio (Dir.), Trattato di procedura penale, vol. VII, Modelli differenziati di accertamento, Tomo I, Turín: Utet Guiridica, 2011, pp. 1029-1135.

GASCÓN INCHAUSTI, Fernando, Proceso penal y persona jurídica, Madrid/Barcelona/Buenos Aires/Sao Paulo: Marcial Pons, 2012.

GIMENO BEVIÁ, Jordi, El proceso penal de las personas jurídicas, Navarra: Aranzadi, 2014.

GÓMEZ-JARA DÍEZ, Carlos, La responsabilidad penal de las empresas en los EE.UU, Madrid: Ramón Areces, 2006.

, "Fundamentos de la responsabilidad penal de las personas jurídicas" en: BAJO FERNÁNDEZ, Miguel; FEIJOO SÁNCHEZ, Bernardo José; GÓMEZ-JARA DÍEZ, Carlos, Tratado de responsabilidad penal de las personas jurídicas. $2^{\mathrm{a}}$ ed. Adaptado a la Ley 1/2105, de 30 de marzo, por la que se modifica el Código Penal, Navarra: Aranzadi, 2016, pp. 89-119.

"El injusto típico de la persona jurídica (tipicidad)" en: BAJO FERNÁNDEZ, Miguel; FEIJOO SÁNCHEZ, Bernardo José; GÓMEZ-JARA DÍEZ, Carlos, Tratado de responsabilidad penal de las personas jurídicas. $2^{\mathrm{a}}$ ed. Adaptado a la Ley 1/2105, de 30 de marzo, por la que se modifica el Código Penal, Navarra: Aranzadi, 2016, pp. 121-141.

"La culpabilidad de la persona jurídica" en: BAJO FERNÁNDEZ, Miguel; FEIJOO SÁNCHEZ, Bernardo José; GÓMEZ-JARA DÍEZ, Carlos, Tratado de responsabilidad penal de las personas jurídicas. $2^{\mathrm{a}}$ ed. Adaptado a la Ley 1/2105, de 30 de marzo, por la que se modifica el Código Penal, Navarra: Aranzadi, 2016, pp. 143-219.

GOÑI SEIN, José Luis, "Programas de cumplimiento empresarial (compliance programs): aspectos laborales", en: MIR PUIG, Santiago; CORCOY BIDASOLO, Mirentxu; GÓMEZ MARTÍN, Víctor (Dirs.); HORTAL IBARRA, Juan Carlos; VALIENTE 
Polít. crim. Vol. 11, No 22 (Diciembre 2016), Art. 5, pp. 467-520.

[http://www.politicacriminal.cl/Vol_11/n_22/Vol11N22A5.pdf]

IBÁÑEZ, Vicente (Coords.), Responsabilidad de la empresa y compliance. Programas de prevención, detección y reacción penal, Montevideo-Buenos Aires: B de F, 2014, pp. 367-419.

GUTIÉRREZ DE CABIEDES Y FERNÁNDEZ HEREDIA, Eduardo, Estudios de Derecho procesal, Pamplona: Eunsa, 1974.

GUTIÉRREZ PÉREZ, Elena, "Los compliance programs como eximente o atenuante de la responsabilidad penal de las personas jurídicas: la eficacia e idoneidad como principios rectores tras la reforma de 2015", Revista General de Derecho Penal, núm. 24 (2015).

HERNÁNDEZ BASUALTO, Héctor, "La introducción de la responsabilidad penal de las personas jurídicas en Chile”, Polít. Crim., vol. 5, no 9 (2010), pp. 207-236.

HUFF, Kevin, "Note: The Role of Corporate "compliance" Programs in Determining Corporate Criminal Liability: A Suggested Approach”, Columbia Law Review, nº 96 (1996), pp. 1252-1298.

JUANES PECES, Ángel, "Necesidades en la regulación procesal de la responsabilidad penal de las personas jurídicas" en: AA.VV., Reforma penal: personas jurídicas y tráfico de drogas; Justicia restaurativa, Cuadernos penales de José María Lidón, $\mathrm{n}^{\circ}$ 8, Bilbao: Publicaciones de la Universidad de Deusto, 2011, pp. 39-44.

LASCURAÍN SÁNCHEZ, Juan Antonio, "La delegación como mecanismo de prevención y de generación de deberes penales" en: NIETO MARTÍN, Adán (Dir.) Manual de cumplimiento penal en la empresa, Barcelona: Tirant lo Blanch, 2015, pp. 165-185.

MARTÍNEZ PÉREZ, Miriam; SANDE MAYO, María Jesús, "La responsabilidad penal de las personas jurídicas” en: CASTILLEJO MANZANARES, Raquel (Dir.); SANDE MAYO, María Jesús (Coord.) Temas actuales en la persecución de los hechos delictivos, Madrid: La Ley, 2012, pp. 373-396.

NIETO MARTÍN, Adán, "Investigaciones internas, whistleblowing y cooperación: la lucha por la información en el proceso penal”, Diario La Ley, nº 8120 (2013).

, "Problemas fundamentales del cumplimiento normativo en el Derecho penal" en: KUHLEN, Lothar; MONTIEL, Juan Pablo; ORTIZ DE URBINA GIMENO, Íñigo (Eds.), Compliance y teoría del Derecho Penal, Madrid: Marcial Pons, 2013, pp. 21-50.

, "Fundamentos y estructura de los programas de cumplimiento normativo" en: NIETO MARTÍN, Adán (Dir.), Manual de cumplimiento penal en la empresa, Barcelona: Tirant lo Blanch, 2015, pp. 111-134.

"Investigaciones internas", en: NIETO MARTÍN, Adán (Dir.), Manual de cumplimiento penal en la empresa, Tirant lo Blanch: Barcelona, 2015, pp. 231-270.

PINOCHET CANTWELL, Francisco José, "Cargas dinámicas de la prueba: El agravamiento en Chile", en: GÓMEZ COLOMER, Juan Luis; BARONA VILAR, Silvia; CALDERÓN CUADRADO, María Pía (Coords.), El Derecho procesal español del siglo XX a golpe de tango. Juan Montero Aroca. Liber Amicorum, en homenaje y para celebrar su LXX cumpleaños, Valencia: Tirant lo Blanch, 2012, pp. 729-760.

PIÑA ROCHEFORT, Juan Ignacio, Modelos de prevención de delitos en la empresa, Chile: Abeledo Perrot, 2012.

PRITTWITZ, Cornelius, "La posición jurídica (en especial posición de garante) de los compliance officers", en: KUHLEN, Lothar; MONTIEL, Juan Pablo; ORTIZ DE 
NEIRA, Ana María. "La efectividad de los criminal compliance programs como objeto de prueba en el proceso penal".

URBINA GIMENO, Íñigo (Eds.) Compliance y teoría del Derecho Penal, Madrid: Marcial Pons, 2013, pp. 207-220.

RIGO, Fabrizio, "Il giudizio" en: AA.VV., La responsabilità amministrativa degli enti. D.lgs. 8 giugno 2001, n. 231, Milán: Ipsoa, 2002, pp. 351- 377.

SALVO ILABEL, Nelly, Modelos de imputación penal a personas jurídicas: estudio comparado de los sistemas español y chileno, Tesis doctoral dirigida por CUGAT MAURI, Miriam, Universidad Autónoma de Barcelona: Barcelona, 2014.

SILVA SÁNCHEZ, Jesús María, "La responsabilidad penal de las personas jurídicas en Derecho español" en: SILVA SÁNCHEZ, Jesús María (Dir.); MONTANER FERNÁNDEZ, Raquel (Coord.), Criminalidad de empresa y Compliance. Prevención y reacciones corporativas, Barcelona: Atelier, 2013, pp. 15-42.

TIEDEMANN, Klaus, "Die "Bebüssung von Unternehmen nach dem 2" Gesetz zur Bekämpfung der Wirtschaftskriminalität", Neue Juristische Wochenschrift, núm. 41 (1988), pp. 1172 y ss.

VAN WEEZEL DE LA CRUZ, Alex, "Contra la responsabilidad penal de las personas jurídicas", Polít. Crim., vol. 5, nº 9 (2010), pp. 114-142.

VARRASO, Gianluca, Il procedimento per gli illeciti amministrativi dipendenti da reato, Milán: Giuffrè, 2012.

VÁZQUEZ SOTELO, José Luis, Presunción de inocencia del imputado e íntima convicción del tribunal. Estudio sobre la utilización del imputado como fuente de prueba en el proceso penal español, Barcelona: Bosch, 1985.

VEGAS TORRES, Jaime, "Problemática procesal derivada de la responsabilidad penal de las personas jurídicas", Diario La Ley, no 7626 (2011).

VELÁZQUEZ VIOQUE, David, "Responsabilidad penal de las empresas. ¿Cómo probar el debido control?", Diario La Ley, no 7794 (2012). 